\title{
SOCIAL PROTECTION RESPONSE TO THE COVID-19 CRISIS IN THE DOMINICAN REPUBLIC
}

\section{World Bank Policy Note}

\author{
January 2021
}


(C) 2021 International Bank for Reconstruction and Development / The World Bank 1818 H Street NW

Washington DC 20433

Telephone: 202-473-1000

Internet: www.worldbank.org

This work is a product of the staff of The World Bank with external contributions. The findings, interpretations, and conclusions expressed in this work do not necessarily reflect the views of The World Bank, its Board of Executive Directors, or the governments they represent.

The World Bank does not guarantee the accuracy, completeness, or currency of the data included in this work and does not assume responsibility for any errors, omissions, or discrepancies in the information, or liability with respect to the use of or failure to use the information, methods, processes, or conclusions set forth. The boundaries, colors, denominations, and other information shown on any map in this work do not imply any judgment on the part of The World Bank concerning the legal status of any territory or the endorsement or acceptance of such boundaries.

Nothing herein shall constitute or be construed or considered to be a limitation upon or waiver of the privileges and immunities of The World Bank, all of which are specifically reserved.

\section{Rights and Permissions}

The material in this work is subject to copyright. Because The World Bank encourages dissemination of its knowledge, this work may be reproduced, in whole or in part, for noncommercial purposes as long as full attribution to this work is given.

Any queries on rights and licenses, including subsidiary rights, should be addressed to World Bank Publications, The World Bank Group, 1818 H Street NW, Washington, DC 20433, USA; fax: 202-5222625; e-mail: pubrights@worldbank.org. 


\section{DOMINICAN REPUBLIC}

\section{GOVERNMENT FISCAL YEAR}

January, 1 - December, 31

CURRENCY EQUIVALENTS

Currency Unit: Dominican Peso (RD\$)

(Exchange Rate Effective as of 5/20/2020)

US\$1.00 = RD\$55.45

\section{Abbreviations and Acronyms}

$\begin{array}{ll}\text { ADESS } & \text { Administrator of Social Subsidies (Administradora de Subsidios Sociales) } \\ \text { BANRESERVAS } & \text { Reserve Bank of the Dominican Republic (Banco de Resrvas de la República } \\ \text { DGII } & \text { Dominicana) } \\ \text { DR } & \text { Dominican Internal Revenue Service (Dirección General de Impuestos Internos) } \\ \text { ENCFT } & \text { Dominican Republic } \\ \text { FASE } & \text { National Labor Force Survey (Encuesta Nacional Continua de Fuerza de Trabajo) } \\ \text { GCPS } & \text { Employee Solidarity Assistance Fund (Fondo de Asistencia Solidaria del } \\ & \text { Empleado) } \\ \text { IDOPRIL } & \text { Social Policy Coordination Cabinet (Gabinete de Coordinación de Políticas } \\ \text { MEPyD } & \text { Sociales) } \\ \text { Dominican Institute for the Prevention and Protection of Occupational Risks } \\ \text { MSMEs } & \text { (Instituto Dominicano de Prevención y Protección de Riesgos Laborales) } \\ \text { PA' TI } & \text { Ministry of Economy, Planning and Development (Ministerio de Economí, } \\ & \text { Planificación y Desarrollo) } \\ \text { PASP } & \text { Micro, small and medium-sized enterprises } \\ \text { PLWDs } & \text { Independent Worker Assistance Program (Programa de Asistencia al Trabajador } \\ \text { PLWHs } & \text { Independiente) } \\ \text { PPP } & \text { Social Assistance Plan of the Presidency (Plan de Asistencia Social de la } \\ \text { QEC } & \text { Presidencia) } \\ \text { QLI } & \text { People living with disabilities } \\ \text { SDSS } & \text { People living with HIV } \\ \text { SIUBEN } & \text { Public-private partnership } \\ \text { TSS } & \text { Stay at Home (Quédate en Casa) } \\ \text { UNDP } & \text { Quality of Life Index } \\ \text { Dominican Social Security System (Sistema Dominicando de Seguridad Social) } \\ \text { Unified Beneficiary Identification System (Sistema Unico de Beneficiarios) } \\ \text { Treasury of Social Security } \\ \text { United Nations Development Programme }\end{array}$




\begin{tabular}{|l|l|}
\hline Vice President: & Carlos Felipe Jaramillo \\
\hline Country Director: & Michel Kerf \\
\hline Global Director: & Marcello Estevão \\
\hline Sector Managers: & $\begin{array}{l}\text { Jorge Thompson Araujo } \\
\text { Pablo Gottret }\end{array}$ \\
\hline Task Team Leader: & $\begin{array}{l}\text { Johannes Herderschee } \\
\text { Miriam Montenegro }\end{array}$ \\
\hline
\end{tabular}




\section{Acknowledgements}

This Policy Note is part of an ongoing dialogue between World Bank staff and the Dominican Republic's Ministry of Finance and Ministry of Planning and Economic Development. The Policy Note supports both the analysis presented in the Public Expenditure Review (PER) series and the monitoring of the implementation of the Dominican Republic COVID-19 Crisis Response Support Development Policy Loan (P174145).

At the Ministry of Finance, the task was managed by Mr. José Luis Actis, Advisor to the Minister until September 2020 and since October 1, 2020 by Mr. Gian Lucas Marra, Advisor to the Minister, and supported by Paola Maria Vargas Antigua, Coordinator, and Camila Hernandez Villamán, Economist. At the Ministry of Economy, Planning and Development, the task was managed by Martin Franco, at the time, Public Finance Unit Coordinator, UAAES, and Paula Salvador, World Bank Group Project Coordinator. Experts from sector ministries were invited to collaborate with the World Bank team on the preparation of each chapter. At the request of the Government of the Dominican Republic, the French Development Agency (Agence Française de Développement, AFD) provided financial support for this project. AFD Director Sandra Kassab was instrumental in the preparation of the analysis, and valuable contributions were made by Eleonore Pocry, Country Officer in charge of DR and Martinique and Gwenola Pellen, Procurement Officer, in Paris and Lucas Gimenez, Project Officer, in Santo Domingo.

This PER series was prepared by an interdisciplinary team led by World Bank staff. Johannes (Han) Herderschee (Senior Country Economist) coordinated the team in close collaboration with Craig Kullmann (Senior Water Supply and Sanitation Specialist, SLCWA), Miriam Montenegro (Senior Social Protection Specialist, HLCSP), James Sampi Bravo (Economist, ELCMU), Anjali Shahani (Operations Officer, LCC3C), and Carmen Amaro (Operations Officer, LCCDO). The Social Protection Team was led by Miriam Montenegro (Senior Social Protection Specialist, HLCSP) and consisted of Maria Concepcion Steta (Senior Social Protection Specialist, HLCSP), Magdalena Lizardo (Consultant, ELCMU), Julian Valdés (Consultant, ELCMU), José Pellerano (Consultant, ELCMU), Daniel de la Rosa (Consultant, ELCMU), and Lisselotte Gálvez (Consultant, ELCMU). The team benefited from guidance and advice provided by Jorge Araujo (Manager, MTI), Rita Cestti (Practice Manager, SLCWA), and Pablo Gottret (Practice Manager, HLCSP). The team would also like to acknowledge the valuable overall guidance and comments provided by Tahseen Sayed Kahn (Country Director for the Caribbean), Michel Kerf (Country Director for Central America and the Dominican Republic), Alessandro Legrottaglie (Country Manager until June 30, 2020), Alexandria Valerio (Country Manager since July 1, 2020), Abha Prasad (Program Leader), Timothy Johnston (Program Leader), and Vickram Cuttaree (Program Leader). Ricardo Habalian (Operations Officer, LCC3C) prepared the first draft of the Executive Summary. Juan Carlos Parra Osorio (Senior Economist, ELCPV until June 30, 2020) and Alejandro De la Fuente (Senior Economist, ELCPV since July 1, 2020) advised on poverty issues and the expenditure-incidence analysis. Sincere thanks are also due to the peer reviewers who contributed at various stages of the analysis, including: Aline Coudouel (Lead Economist HSASP), Mark Charles Dorfman (Senior Economist, HEASP), Henri Fortin (Lead Financial Management Specialist, EA2G2), Chris Heymans (Senior Water and Sanitation Specialist, SAFW3), Phil Keefer (Principal Economic Advisor, IDB), Professor Thierry Madies (University of Fribourg), and Guillermo Javier Vuletin (Senior Economist, LCRCE). 
The team would also like to thank Sean Lothrop (Consultant) and Oscar Parlback (Consultant) for muchvalued assistance in revising drafts and editing the PER. Sylvaine Cussac (Consultant) formatted this version. Giselle Velasquez (Program Assistant, ELCMU) greatly supported this work by tirelessly facilitating administrative processes. Maria Hermann (Executive Assistant in the World Bank's Santo Domingo office) and Samahara Hernandez Angulo (Team Assistant in the Santo Domingo office) supported the numerous consultations of the visiting missions.

The Policy Note titled "Social Protection Response to the Covid-19 Crisis in the Dominican Republic" was prepared by a team led by Miriam Montenegro (Senior Social Protection Specialist, HLCSP) and consisting of Maria Concepcion Steta Gandara (Senior Social Protection Specialist, HLCSP), Magdalena Lizardo (Consultant, ELCMU), Pamela Suero (Consultant, ELCMU) and Ursula Milagros Martinez Angulo (Consultant, HLCSP). The team would like to thank Rosa Suarez at the time Social Cabinet Director, Hector Medina at the time Director of PROSOLI, Matilde Chavez at the time Director of SIUBEN and Julissa Holguin at the time Head of the Policy Unit at the Social Cabinet. The team is also grateful for peer reviewer comments from Miriam Muller (Social Scientist, ELCPV) and Timothy Johnston (Program Leader, HLCDR). 


\section{Table of contents}

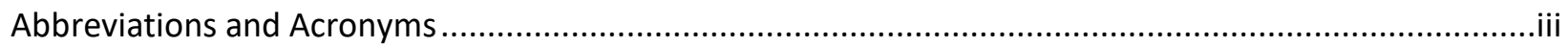

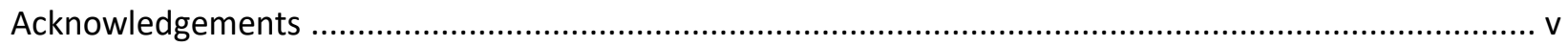

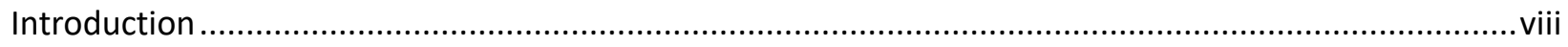

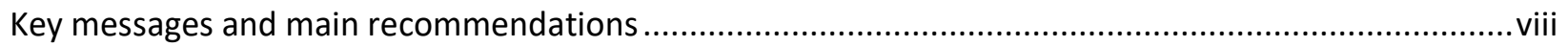

I. The Dominican Economy during the COVID-19 Pandemic............................................................ 1

II. Analysis of the three main safety nets response programs: QEC, FASE, and PA' $\mathrm{TI}$....................... 6

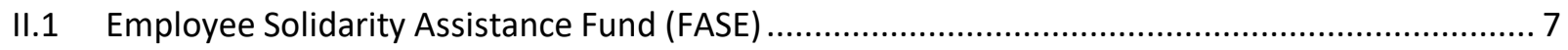

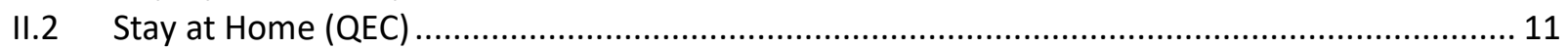

II.3 Independent Worker Assistance Program (PA' TI) ............................................................ 17

III. Social Protection Expenditure and poverty mitigation of the three emergency cash transfer

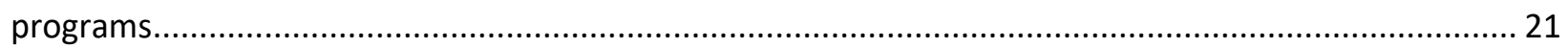

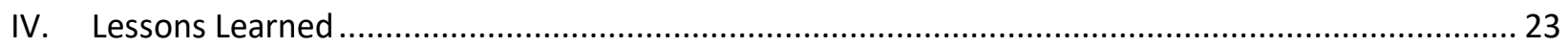

IV.1 Government Agility and Flexibility in the Pandemic Response ............................................. 23

IV.2 Coverage Gaps and Underserved Populations ............................................................ 23

IV.3 The Pandemic Underscored the Need for an Adaptive Social Protection System .................... 24

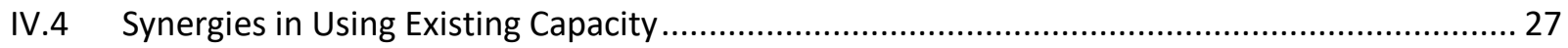

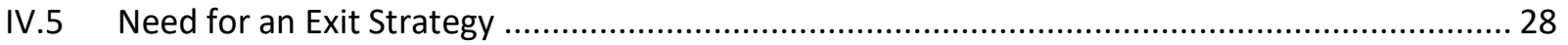

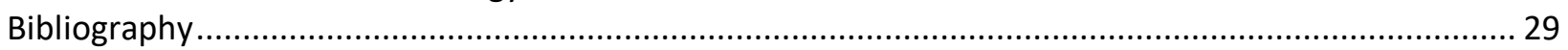

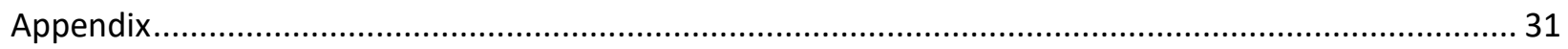

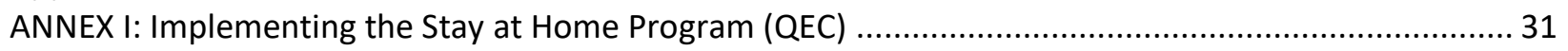

ANNEX II: Implementing the Labor Assistance Fund Program (FASE) ….............................................. 37

ANNEX III: Implementing the Self-Employment Assistance Program (PA'TI) ......................................... 42

\section{List of figures}

Figure 1. Interannual Growth Rate of the Monthly Economic Activity Index, Jan-Sep 2020 with respect

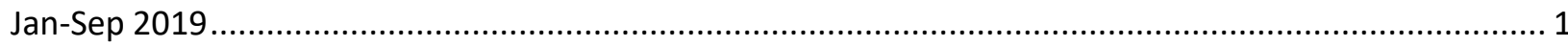

Figure 2. Number of Workers Contributing to the Social Security System by Business Size, April 2019-

September 2020

\section{List of tables}

Table 1. Number of Active Workers Contributing to the Social Security System by Business Size, MarchJuly 2020 3

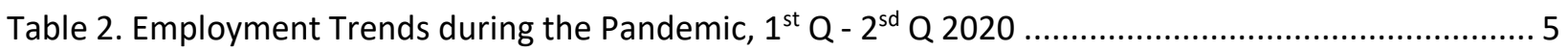

Table 3. Population Living in Monetary and Structural Poverty......................................................... 7

Table 4. Budgeted vs Actual Social Protection Expenditure Related to COVID-19, Apr-Dec 2020 ............ 22 


\section{Introduction}

The Government of the Dominican Republic (DR) adopted a series of economic and social measures to protect households and businesses and prevent employment losses as a response to the COVID-19 health and economic crisis. In March 2020, the DR government declared the state of emergency to prevent the spread of the virus. Containment efforts included the temporarily shutdown of most businesses and widespread restrictions on travel and mobility. As of October 16, 2020, the DR registered 120,450 cases of COVID-19 and 2,192 related deaths. The crisis negatively affected employment, labor income, poverty and vulnerability. The DR government expanded existing social protection programs and created new social programs to protect the poor and vulnerable in an effort to respond to the crisis.

Social Protection policies and programs have been used globally as effective mechanisms to respond to the economic crisis due to the COVID-19 pandemic. As of December 11, a total of 215 countries or territories have planned or implemented 1,414 social protection measures. Social assistance accounts for most, or $62 \%$, of global responses, with cash transfers emerging as the most widely used form of social assistance ( $53 \%$ of total social assistance). Social insurance accounts for $24 \%$ and labor markets for $14 \%$ of the global social protection measures ${ }^{1}$.

This Policy Note aims to document and analyze the design and implementation of the three main cashtransfer programs that the government used to protect households and workers affected by the COVID19 crisis. The programs that are part of the scope of the note are: 1) Stay at Home (Quédate en Casa, QEC), 2) the Employee Solidarity Assistance Fund (Fondo de Asistencia Solidaria del Empleado, FASE), and 3) the Independent Worker Assistance Program (Programa de Asistencia al Trabajador Independiente, PA' $\mathrm{TI})$. The analysis of these programs is based on a desk review of administrative and legal documents, media information, program reports, and operational rules. The Policy Note is organized as follows: First, it provides an overview of the impact of COVID-19 on the economy and identifies the potentially affected population. Second, it provides a description of the design and implementation of the three social protection programs and their expenditures. Finally, it discusses lessons learned, including challenges and opportunities to improve social protection policies, based on an adaptative social protection framework. In addition, the programs' operational details are described in the Annexes.

\section{Key messages and main recommendations}

- A well-established social protection system allowed the Dominican government to swiftly address the socioeconomic impact of the COVID-19 pandemic. Having a social protection system with a consolidated delivery systems provided the right environment for the role out of three innovative emergency cash transfer programs reaching appropriated levels of coverage of poor and vulnerable households. Coverage of the poor was more appropriate than coverage of specific vulnerable groups, as the noncontributory social protection system was designed to support structural poverty and not transient poverty and the contributory system does not coverage informal workers. However, in spite of the structural challenges to reach out certain vulnerable groups such as low-income formal workers, independent workers, and vulnerable informal workers, the DR government made great efforts and achieved substantial results with the QEC, FASE and PA'TI programs.

\footnotetext{
${ }^{1}$ Gentilini et al. (2020). Social Protection and Jobs Responses to COVID-19: A Real-Time Review of Country Measures.
} 
- An Adaptive Social Protection System that can effectively expand in times of crisis would provide a better avenue to respond to future crisis. The pandemic highlighted the imperative need for an adaptive social protection (ASP) system that more effectively helps households and individuals adapt, prepare for, cope with and recover from the impact of shocks. To be more adaptive, the DR social protection system needs to establish:

- At the policy level: ASP specific institutional arrangements, supported by policy and legislation

- At the operational level: Clearly defined operational processes developing operations manuals, protocols guidelines and procedures for new programs or components to improve accountability and transparency.

- At the delivery system level: The Dominican Republic social protection system has a wellestablished delivery system for its cash transfer programs. However, it needs to be more flexible in order to adequately respond to crisis. Some of the challenges are:

- Beneficiary Identification: SIUBEN needs to evolve into a national registry with universal coverage, more flexibility and the ability to identify all types of vulnerabilities to allow policy makers to adopt effective social protection policies in response to the pandemic and other emergency situations.

- Payment System: ADESS payment system need to provide sufficient options and flexibility for changing or adjusting benefit delivery mechanisms in times of crisis.

- Monitoring and Evaluation: There is a need to strengthen government capacity to monitor the situation of beneficiaries and underserved populations to be able to swiftly respond to their changing needs.

- Coordination Arrangements are a key component for crisis response. The pandemic emergency response plan demonstrated that intersectoral and interinstitutional coordination is possible to effectively address the needs of the most vulnerable. These arrangements need to be further institutionalized and strengthened.

- The DR government needs to develop a plan to transition from emergency response to economic recovery. There is unlocked potential to use the country's social safety nets in the economic recovery phase of the pandemic. The DR government should develop a transition strategy from emergency response to economic recovery. The transition strategy should take into account: 1 ) the world's economic recovery estimates; 2 ) The phase-out of the three main emergency cash transfer programs; 3) key lessons learned from the emergency response; 4) the local capacity, 5) the links between social protection and economic inclusion policies and programs. 


\section{The Dominican Economy during the COVID-19 Pandemic}

1. The emergency response to the COVID-19 crisis imposed severe restrictions to the mobility of people and businesses. On March 19, 2020, the Dominican Republic (DR) government declared a nationwide state of emergency. Due to the severity of the crisis, the state of emergency was extended on six occasions until it was temporarily lifted (only 20 days) in June. However, on July $20^{\text {th }}$, the government reinstated the state of emergency until October $18^{\text {th }}$. The restrictions to mobility under the October extension were less severe than those adopted at the onset of the pandemic as the government started the phased-out plan. The government has extended the state of emergency for an additional 45 days until December $2^{\text {nd }}$.

2. Mobility restrictions imply sharp GDP contractions. In the first half of 2020, the Dominican economy contracted by 8.5 percent compare to the same period in 2019. These sharp contractions are unprecedented in the country's recent economic history (Figure 1). The COVID-19 downturn is worse than the economic contraction during the 2003 banking crisis (-1.3 percent) and the economic contraction during the 2008 great recession (-2.4 percent). The crisis was most severe in April 2020 and, to a lesser extent, in May 2020, when comparing with the same period in 2019. Between January and May of 2020, the hardest-hit sectors, in terms of a real value-added contraction, were hotels, bars, and restaurants (42.6 percent); construction (-23.2 percent); mining (-16.3 percent); other services (-11.7 percent); transportation and storage (-11.0\% percent); free trade zones $(-9.8$ percent), and local manufacturing (7.8 percent). ${ }^{2}$ In late May, the government began the scale-down of the lockdown, allowing some businesses to partially and progressively restart their operations. As a result, economic activity partially recovered from June onwards. However, key sectors such as tourism continue to operate on a very low capacity. ${ }^{3}$ The extent of any subsequent recovery in output will depend on the effectiveness of the policy actions taken to support workers and business through the downturn and the extent to which confidence returns.

Figure 1. Interannual Growth Rate of the Monthly Economic Activity Index, Jan-Sep 2020 with respect Jan-Sep 2019

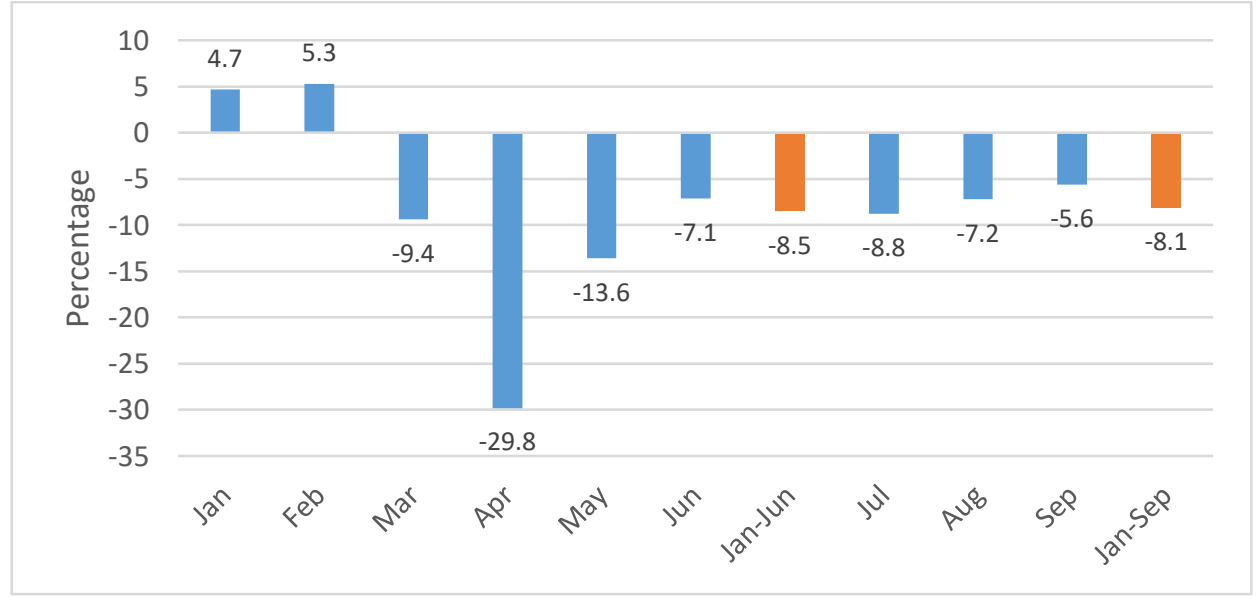

Source: Author's estimates based on data from the Central Bank of the DR.

\footnotetext{
${ }^{2}$ Digepres (2020). “Mid-Year Report on the 2020 National Budget. Page. 15.

${ }^{3}$ On August 26, Tourism Minister David Collado reported hotels averaged 5\% occupancy of total available rooms. https://eldia.com.do/ocupacion-hotelera-en-el-pais-ronda-el-5-informa-david-collado/.
} 
3. The COVID-19 crisis is having a significant impact on employment. Information from the Treasury of Social Security (TSS) shows that in April and May the number of active workers contributing to the Dominican Social Security System (Sistema Dominicano de Seguridad Social, SDSS) fell by 532,342 workers, representing a 23.7 percent loss of formal employment (Figure 2). The partial economic recovery in June and July helped to regain 50 percent of jobs losses in the formal sector in April-May. In July 2020, 1,984,078 workers were formally employed, 11.8 percent less than in March 2020. Job creation in the formal sector for the August-September period was modest (7,521 additional jobs).

Figure 2. Number of Workers Contributing to the Social Security System by Business Size, April 2019September 2020

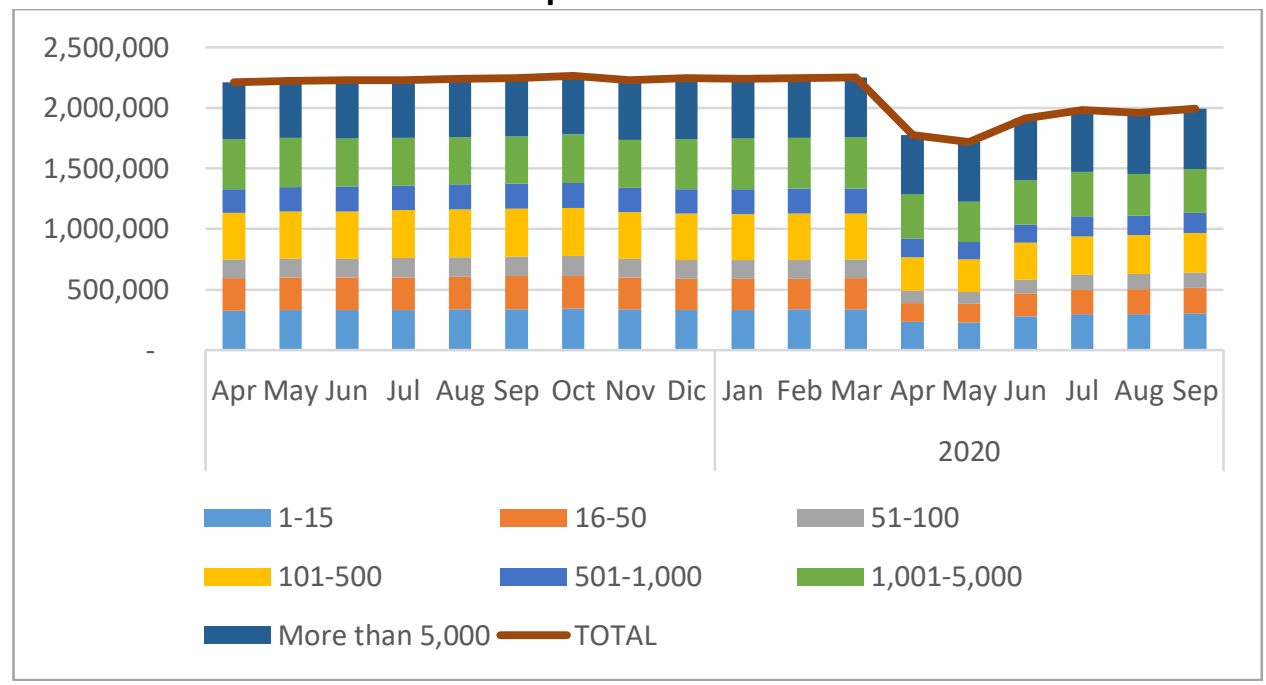

Source: Author's estimates based on data from the TSS.

4. While the contraction of formal employment affected firms of all sizes, smaller enterprises have been particularly affected. In the period Mar-May of 2020, formal employment-measured as the number of workers contributing to social security - fell by 40 percent in the case of small enterprises (1650 workers), a much higher percentage comparing with large enterprises (over 500 workers) where formal employment fell by 13.8 percent (Table 1). As large enterprises represent 50 percent or more of formal jobs, 52 percent of the fall in total formal employment during the pandemic, was due to job losses in very large enterprises ( 29 percent in firms with $>500$ workers) and large enterprises ( 22 percent in firms with 101-500 workers). By contrast, 38.5 percent of the fall in formal employment came from micro (17.0 percent) and small (21.5 percent) enterprises between March and July 2020. 
Table 1. Number of Active Workers Contributing to the Social Security System by Business Size, March-July 2020

\begin{tabular}{|c|c|c|c|c|c|c|}
\hline \multirow[t]{2}{*}{ Period } & \multicolumn{5}{|c|}{ Business size by the number of workers } & \multirow[t]{2}{*}{ TOTAL } \\
\hline & $1-15$ & $16-50$ & $51-100$ & $101-500$ & $>500$ & \\
\hline \multicolumn{7}{|c|}{ Number of workers } \\
\hline Mar & 339,268 & 257,707 & 153,911 & 376,839 & $1,122,415$ & $2,250,140$ \\
\hline May & 230,077 & 153,009 & 96,667 & 270,637 & 967,408 & $1,717,798$ \\
\hline Jul & 294,022 & 200,537 & 126,459 & 317,905 & $1,045,155$ & $1,984,078$ \\
\hline \multicolumn{7}{|c|}{ Percentage distribution } \\
\hline Mar & 15.1 & 11.5 & 6.8 & 16.7 & 49.9 & 100.0 \\
\hline May & 13.4 & 8.9 & 5.6 & 15.8 & 56.3 & 100.0 \\
\hline Jul & 14.8 & 10.1 & 6.4 & 16.0 & 52.7 & 100.0 \\
\hline \multicolumn{7}{|c|}{ Absolute variation } \\
\hline Mar-May & $-109,191$ & $-104,698$ & $-57,244$ & $-106,202$ & $-155,007$ & $-532,342$ \\
\hline May-Jul & 63,945 & 47,528 & 29,792 & 47,268 & 77,747 & 266,280 \\
\hline Mar-Jul & $-45,246$ & $-57,170$ & $-27,452$ & $-58,934$ & $-77,260$ & $-266,062$ \\
\hline \multicolumn{7}{|c|}{ Relative variation \% } \\
\hline Mar-May & -32.2 & -40.6 & -37.2 & -28.2 & -13.8 & -23.7 \\
\hline May-Jul & 27.8 & 31.1 & 30.8 & 17.5 & 8.0 & 15.5 \\
\hline Mar-Jul & -13.3 & -22.2 & -17.8 & -15.6 & -6.9 & -11.8 \\
\hline \multicolumn{7}{|c|}{ Relative variation incidence } \\
\hline Mar-May & -4.9 & -4.7 & -2.5 & -4.7 & -6.9 & -23.7 \\
\hline May-Jul & 3.7 & 2.8 & 1.7 & 2.8 & 4.5 & 15.5 \\
\hline Mar-Jul & -2.0 & -2.5 & -1.2 & -2.6 & -3.4 & -11.8 \\
\hline \multicolumn{7}{|c|}{ Percentage distribution of incidence rate by business size in relative variation } \\
\hline Mar-May & 20.5 & 19.7 & 10.8 & 19.9 & 29.1 & 100.0 \\
\hline May-Jul & 24.0 & 17.8 & 11.2 & 17.8 & 29.2 & 100.0 \\
\hline Mar-Jul & 17.0 & 21.5 & 10.3 & 22.2 & 29.0 & 100.0 \\
\hline
\end{tabular}

Source: Author's elaboration based on data from the TSS.

5. Between March and June, 359,180 formal and informal workers lost their jobs, representing a $\mathbf{7 . 8 \%}$ contraction when comparing with Jan-Mar 2020 (Table 2). The employment contraction was larger in the informal sector (-10.0 percent) than in the formal sector (-5.1 percent). An analysis of the National Labor Force Survey (Encuesta Nacional Continua de Fuerza de Trabajo, ENCFT), shows that salaried workers accounted for an estimated 52 percent of all workers who lost their jobs, 49.5 percent of these workers were employed in the formal sector. By contrast, self-employed workers represented 14.3 percent of all workers who lost their jobs in the same period. While formal self-employment increased by 12,734 workers, informal self-employment contracted by 64,234 workers. Domestic employment also contracted significantly by 70,460 workers, of which 98.2 percent were informal workers. According with the ENCFT, during Apr-Jun, the participation rate decreased in -6.7 percentage when compare to the situation in Jan-Mar, which implies that 497,442 individuals exit the open economically active population ${ }^{4}$. Although, the open unemployment rate decreased from 5.7 percent in the first quarter of 2020 to 3.7 percent in the second quarter, there was a significant increase ( 3 percentage points) in the unemployed and potential labor force ${ }^{5}$ during the first three months of the pandemic.

\footnotetext{
${ }^{4}$ The open economically active population includes the employed workforce, and the unemployed workforce that has been actively looking for a job four weeks prior to the survey.

${ }^{5}$ The potential workforce includes people not seeking for a job four weeks prior to the survey but would have accepted one if offered, as well as people that sought for a job but it was not longer available at the time of the survey.
} 


\section{The economic crisis due to the COVID-19 pandemic has increased poverty and vulnerability in} the DR. The Ministry of Economy, Planning and Development (Ministerio de Economía, Planificación y Desarrollo, MEPyD) estimates that during the second quarter of 2020 (2020Q2), when the country was in full lockdown, the general poverty rate was $27.4 \%$, an increase of 6 percentage points, when compare to the $21.4 \%$ poverty rate in the first quarter (2020Q1). The moderate poverty rate increased by 3.9 percentage points from $18.4 \%$ (2020Q1) to $22.3 \%$ (2020Q2). Likewise, the extreme poverty rate increased by 2.1 percentage points from $3.0 \%$ (2020Q1) to $5.1 \%$ (2020Q2) ${ }^{6}$. Regarding the vulnerable population, the population living on less than US \$ 10 PPA per day increased from 63\% in June 2019 to $70 \%$ in June $2020^{7}$, an increase of 7 percentage points. The total impact on the annual poverty rate is linked to the duration of the crisis, the speed of the economy recovery and the duration of the emergency response, mainly the three cash transfer programs. Given the temporary drop in labor income, a fraction of households may have used assets to avoid the drop in their consumption that affect their ability to recover or facilitate their upward economic mobility in the future.

\footnotetext{
${ }^{6}$ MEPyD (2020). Pages 8 and 9.

${ }^{7}$ MEPyD (2020). Pages 8 and 9.
} 
Table 2. Employment Trends during the Pandemic, $1^{\text {st }} Q-2^{\text {sd }} Q 2020$

\begin{tabular}{|c|c|c|c|c|c|c|}
\hline & \multicolumn{2}{|c|}{ 1st. quarter 2020} & \multicolumn{2}{|c|}{ 2nd. Quarter } & \multirow{2}{*}{$\begin{array}{l}\text { Absolute } \\
\text { Variation }\end{array}$} & \multirow{2}{*}{$\begin{array}{c}\% \\
\text { Relative } \\
\text { variation }\end{array}$} \\
\hline & Number & $\%$ & Number & $\%$ & & \\
\hline Formal workers & $2,074,425$ & 45.0 & $1,967,741$ & 46.3 & $-106,684$ & -5.1 \\
\hline Salaried workers & $1,963,892$ & 42.6 & $1,871,010$ & 44.1 & $-92,882$ & -4.7 \\
\hline Employers & 79,275 & 1.7 & 54,000 & 1.3 & $-25,275$ & -31.9 \\
\hline Self-employed & 23,284 & 0.5 & 36,018 & 0.8 & 12,734 & 54.7 \\
\hline \multicolumn{7}{|l|}{ Unpaid family workers } \\
\hline Domestic worker & 7,975 & 0.2 & 6,714 & 0.2 & $-1,261$ & -15.8 \\
\hline Informal workers & $2,531,449$ & 55.0 & $2,278,953$ & 53.7 & $-252,495$ & -10.0 \\
\hline Salaried workers & 499,071 & 10.8 & 404,384 & 9.5 & $-94,686$ & -19.0 \\
\hline Employers & 82,086 & 1.8 & 63,233 & 1.5 & $-18,853$ & -23.0 \\
\hline Self-employed & $1,637,101$ & 35.6 & $1,572,867$ & 37.0 & $-64,234$ & -3.9 \\
\hline Unpaid family workers & 61,363 & 1.3 & 55,840 & 1.3 & $-5,522$ & -9.0 \\
\hline Domestic worker & 251,829 & 5.5 & 182,629 & 4.3 & $-69,199$ & -27.5 \\
\hline Total General & $4,605,874$ & 100.0 & $4,246,695$ & 100.0 & $-359,180$ & -7.8 \\
\hline Salaried workers & $2,462,963$ & 53.5 & $2,275,394$ & 53.6 & $-187,569$ & -7.6 \\
\hline Employers & 161,361 & 3.5 & 117,233 & 2.8 & $-44,128$ & -27.3 \\
\hline Self-employed & $1,660,385$ & 36.1 & $1,608,884$ & 37.9 & $-51,500$ & -3.1 \\
\hline Unpaid family workers & 61,363 & 1.3 & 55,840 & 1.3 & $-5,522$ & -9.0 \\
\hline Domestic worker & 259,804 & 5.6 & 189,344 & 4.5 & $-70,460$ & -27.1 \\
\hline \multicolumn{7}{|l|}{ Memo } \\
\hline Global participation rate & 63.4 & & 56.7 & & -6.7 & \\
\hline Occupation rate & 59.8 & & 54.9 & & -4.9 & \\
\hline Unemployment rate & 5.7 & & 3.2 & & -2.5 & \\
\hline $\begin{array}{l}\text { Unemployment and } \\
\text { potential labor force rate }\end{array}$ & 12.5 & & 15.5 & & 3.0 & \\
\hline
\end{tabular}

Source: Author's elaboration based on Central Bank. 


\section{Analysis of the three main safety nets response programs: QEC, FASE, and PA' TI}

7. The Government's main social response to the COVID-19 crisis focused on the expansion of existing social programs and the creation of new emergency programs. Immediately after declaring the state of emergency and imposing restriction to mobility the government created two new social program to support the income of poor and vulnerable households: the Employee Solidarity Assistance Fund (Fondo de Asistencia Solidaria del Empleado, FASE) and the Stay at Home Program (Quédate en Casa, QEC). The FASE program target population are formal wage workers who are at high risk of losing their jobs. The QEC program target population are households that are structurally poor (QLI 1 and 2) as well as vulnerable households (QLI 3). The severity of the crisis and the lack of safety nets for some vulnerable groups, led the Government to create an additional program, the Independent Worker Assistance Program (Programa de Asistencia al Trabajador Independiente, PA' TI). The PA'TI program target population are vulnerable self-employed workers.

8. Despite a well-established social registry for cash transfer programs, the government faced problems identifying key vulnerable groups for its COVID-19 social response. The Unified Beneficiary Identification System (Sistema Único de Beneficiarios, SIUBEN) provides information on poverty and other economic variables for roughly $60 \%$ of the Dominican Republic Population. SIUBEN main targeting methodology is the Quality of Life Index (QLI), a multidimensional measurement of structural poverty that uses the proxy means test (PMT) methodology. The QLI classifies households into four groups: QLI 1 multidimensional extreme poor; QLI 2 multidimensional moderate poor; QLI 3 multidimensional non-poor and vulnerable; and QLI 4 multidimensional non-poor and non-vulnerable. SIUBEN mechanisms for targeting and identifying beneficiaries are circumscribed to target structural poverty and not adaptable for identifying households in situations of transient poverty such it is the case of many COVID-19 affected households and individuals. SIUBEN does not include information on income level. The National Labor Force Survey (ENCFT) provides information on household and individual's income but is based on a sample and does not allow for the identification of households or individuals. As both sources of information include different universes and variables for measuring poverty, and there is not an established methodology to link and use the information from both sources in a complementary manner, it is hard to identify the total universe of households and individuals needing support. For example, SIUBEN reports 150,941 extreme multidimensional poor households (QLI 1) and at the onset of the COVID pandemic the ENCFT most recent data (2019) showed 62,531 households living in extreme monetary poverty (Table 3). Given these limitations of administrative data and surveys available, the government could only identify households with the available data on SIUBEN and other administrative databases with very limited information, which led to some exclusion/inclusion errors. Due to the severity and nature of the COVID19 crisis, the government social response should include and be able to clearly identify: (i) workers who have lost their jobs due to the pandemic; (ii) people living in monetary or structural poverty; and (iii) vulnerable households. ${ }^{8}$

\footnotetext{
${ }^{8}$ However, it is not possible to accurately target these populations due to shortcomings in existing data.
} 
Table 3. Population Living in Monetary and Structural Poverty

\begin{tabular}{|c|c|c|c|c|}
\hline & \multicolumn{2}{|c|}{ Individuals } & \multicolumn{2}{|c|}{ Households } \\
\hline & Individuals & $\%$ & Number & $\%$ \\
\hline \multicolumn{5}{|c|}{ MULTIDIMENSIONAL POVERTY QLI 2018 (SIUBEN) } \\
\hline Extremely poor (QLI 1) & 552,165 & 5.4 & 218,934 & 6.7 \\
\hline Moderately poor (QLI 2) & $2,549,030$ & 24.8 & 808,554 & 24.6 \\
\hline Vulnerable non-poor (QLI 3) & $4,567,759$ & 44.5 & $1,402,259$ & 42.7 \\
\hline Non-poor (QLI 4) & $2,596,329$ & 25.3 & 854,312 & 26.0 \\
\hline Total & $10,265,279$ & 100.0 & $3,284,059$ & 100.0 \\
\hline \multicolumn{5}{|c|}{ MONETARY POVERTY 2019 (SISDOM) } \\
\hline Monetary poverty & $2,166,040$ & 20.9 & 521,745 & 15.5 \\
\hline Extremely poverty & 273,476 & 2.6 & 62,531 & 1.9 \\
\hline Moderately poor & $1,892,564$ & 18.3 & 459,214 & 13.7 \\
\hline \multicolumn{5}{|c|}{ MULTIDIMENSIONAL POVERTY QLI 2019 (SISDOM) } \\
\hline Total poor & $2,245,696$ & 21.7 & 790,035 & 22.8 \\
\hline Extremely poor (QLI 1) & 347,717 & 3.4 & 150,941 & 4.4 \\
\hline Moderately poor (QLI 2) & $1,897,979$ & 18 & 639,094 & 18 \\
\hline
\end{tabular}

Source: Author's elaboration, based on MEPyD information and SIUBEN database.

\section{II.1 Employee Solidarity Assistance Fund (FASE)}

9. The government created FASE to protect the income of formal workers. The lockdown forced the suspension of all in-person operations across all economic sectors, except for essential sectors such as health services, food distribution, medicine, fuel, and banking services. Consequently, many companies fully or partially suspended their workforce. The FASE program was created by Decree 143-20 to protect the income of formal workers whose companies completely or partially suspended operations as a result of the lockdown. The Dominican Labor Code, ${ }^{9}$ allows the non-payment of wages during a company's suspension period. The FASE program was designed to partially maintain the income of suspended employees. On May 29, 2020, Decree 184-20, scaled up the program and incorporated additional eligibility criteria for FASE 2. FASE 2 supports employees of companies that continued operating during the lockdown or resumed activities as part of the de-escalation of the lockdown. FASE 2 also added employees of companies that ceased operations but kept all their workforce on payroll and kept contributing to the TSS.

10. FASE 2 expanded the coverage of the program. FASE 1 targets workers with suspended employment contracts and excluded companies in fourteen essential production activities. FASE 2 expanded the target population to include workers with active employment contracts as well as expanded the universe of companies in economic sectors previously excluded by FASE 1. FASE 2 benefits employees of companies that continued to operate during the lockdown, including manufacturing companies, micro, small and medium-sized enterprises (MSMEs) and large businesses in eligible sectors. Employers needed to be up to date with their social security contributions to February 2020.

\footnotetext{
${ }^{9}$ Article 51 of the Labor Code states that the employer may suspend the payment of staff wages when, due to Acts of God or Force Majeure, the work must be temporarily interrupted. Said suspension shall be valid for 90 days, which may be extended for justifiable grounds. During said suspension, the worker shall keep his job and labor benefits, and is to be reinstated once the company resumes operations.
} 
11. The government fully or partially subsidizes the salary of workers, depending on their income level and the FASE modality. Workers under FASE 1 who earn less than RD\$5,000 (US\$90.2) per month receive a monthly cash transfer of $\mathrm{RD} \$ 5,000$ fully paid by the government. Workers with a monthly salary exceeding $\operatorname{RD} \$ 5,000$ receive a monthly cash transfer equivalent to 70 percent of their wages, up to a maximum of RD\$8,500 (US\$153.3) per month per worker. When applicable, the employer is encouraged to voluntarily pay for the remaining amount necessary to complete the worker's monthly salary, in the case of workers that have not been suspended. With FASE 2 the government provides a monthly cash transfer of $\mathrm{RD} \$ 5,000$ as a salary advance, but the company is liable for paying the remaining amount to complete the full salary and to pay any additional labor costs (e.g., bonuses or social security contributions).

12. The implementation of FASE involved multiple agencies. The Ministry of Finance (MH, Spanish acronym) and the Ministry of Labor (MT, Spanish acronym) manage FASE with the support of Dominican Social Security System agencies (SDSS, Spanish acronym) and the Reserve Bank of the Dominican Republic (BANRESERVAS, Spanish acronym). The MT oversaw the identification, registration and processing of the payroll of participants. Application to FASE is an on-demand process. Eligible employers submit their applications to the MT. The MT receives applications from beneficiary companies, validates the information with the TSS, process the payroll, and request the payment to the $\mathrm{MH}$. As of July 8 th, $11.4 \%$ of FASE I and $27 \%$ of FASE II applications had been rejected. ${ }^{10}$ The $\mathrm{MH}$ approves payments and informs beneficiary companies and workers once payments are processed. FASE benefits are paid to the beneficiary's payroll account. In the case of workers without bank accounts, BANRESERVAS created a bank account for the worker. As such, the FASE program has also contributed to the financial inclusion of vulnerable workers by increasing the access to bank accounts. FASE benefits are not subject to any withholding of taxes, even when computing the annual Christmas bonus (13th salary) or social security contributions.

13. SDSS agencies provided budget support to FASE and complemented the program by maintaining the health insurance coverage for of suspended workers. The FASE program is funded by the national budget and by reserves from the Dominican Institute for the Prevention and Protection of Occupational Risks (IDOPRIL). Law № 397-19, which created IDOPRIL, contemplates the use of funds, from past contributions, profits, or benefits accumulated in managing the Labor Risk Insurance scheme, for projects and programs aiming to protect the income, social well-being, occupations, or health of workers.[1] Additionally, and as a complementary measure, The National Social Security Council, under the SDSS, ensured the continuation of coverage of the Family Health Insurance for suspended workers, including their direct and additional dependents, contributing to the protection of vulnerable workers during the crisis.

14. FASE's communication strategy includes digital and printed media and direct communication of government officials. Program communication strategy includes presidential and ministerial briefings; interviews and press releases; $\mathrm{MH}$ and $\mathrm{MT}$ social media; virtual conferences; digital publications;

\footnotetext{
${ }^{10}$ According to the Labor Market Observatory (Observatorio del Mercado Laboral Dominicano) (2020), as of July 8th employers submitted 1,153,501 applications for FASE I and 806,396 application for FASE II. The Ministry of Labor denied the inclusion of 131,593 workers in FASE I and 94,292 workers in FASE II.

${ }^{[1]}$ Article 21 of Law № 397-19.
} 
discussion forums in the $\mathrm{MH}^{\prime}$ institutional portal. Additionally, the $\mathrm{MH}$ has a dedicated web portal ${ }^{11}$ for the FASE and QEC programs ${ }^{12}$ and a dedicated telephone for FASE and the PA' TI programs.

15. It is unknown whether FASE includes as part of its delivery system a monitoring and evaluation and grievances and redress mechanisms. A grievances and redress mechanism is key to incorporated users feedback, especially for a new and massive program such as FASE. Some adjustments were made in response to claims on payment delays publicly made by beneficiaries. In July 2020 , the MH reported delays in the disbursement of program funds, as the system governing FASE's internal processes went through a series of adjustments, following the extension of the program. ${ }^{13}$ As of July 13,2020 , the MH reported that 905,857 workers employed by 51,572 companies received FASE benefits, totaling RD\$20,162.5 million (US\$353.2 million). ${ }^{14}$

\footnotetext{
${ }^{11}$ http://fase.mt.gob.do/web/

${ }^{12}$ https://www.hacienda.gob.do/consulta-afiliacion-fase/ and https://www.quedateencasa.gob.do/Default.aspx

${ }^{13}$ As reported by the Ministry of Finance.

${ }^{14}$ Exchange rate 57.0825, corresponding to average rate reported for April - July 2020
} 


\section{Labor Assistance Fund (FASE)}

1. Announcement date

2. Effectiveness

3. Regulatory instruments

4. Goal

5. Target population

6. Eligibility restrictions

\section{Non-eligible populations}

\section{Benefits}

\section{Frequency}

10. Implementing entities

11. Sources of Information and key partners

12. Implementation arrangements
March 25 th, 2020

From April through December 2020

- Decree № 143-20, dated April 2, 2020 (establishment); Decree № 184-20, dated May 29, 2020 (expansion); Decree № 242-20, dated July 8, 2020 (extension to August 16); Decree № 358-20 (extension to December).

Mitigate the negative economic impact of social-distancing and lockdown measures on formal workers.

- Modality FASE 1 Mode: Formal-sector workers with suspended labor contracts.

- Modality FASE 2: Formal-sector workers with active employment contracts.

Not eligible for FASE:

1. Workers of companies that had outstanding social security obligations up until February of 2020.

2. Employees in large companies (other than MSMEs), including: supermarkets, grocery stores, pharmacies, and any commercial establishment selling raw food, medicines, and hygiene products; logistics, distribution, and transportation companies shipping unprocessed materials and finished products for industry, agro-industry, and food; agriculture, livestock, and fishing companies; food industries; mining and quarrying businesses; food, pharmaceutical, and agroindustrial distribution warehouses; financial companies, pension fund administrators, occupational risk administrators, and insurance companies; companies involved in power generation; health companies (with exceptions); and telecommunications companies.

Formal-sector workers of companies that are not in good standing with their social security obligations; workers of companies not eligible for FASE; informal-sector workers; PA'TI and QEC beneficiaries; and undocumented workers.

- $\quad$ FASE 1: DR\$5,000 at 70 percent of salary, as at February 29, 2020, not exceeding $\mathrm{RD} \$ 8,500$.

- $\quad$ FASE 2: DR\$5,000.

Monthly, paid every two weeks.

Ministry of Labor and Ministry of Finance.

The Dominican Institute for the Prevention and Protection of Occupational Risks, TSS, eligible companies, and BANRESERVAS.

The program is coordinated between the Ministry of Labor, Ministry of Finance, and the TSS, which exchange information to verify the eligibility of applicants once applications are received from eligible employers on behalf of their workers. The Ministry of Finance processes the payments following payrolls sent by the Ministry of Labor. 


\section{Communication strategy}

\section{Monitoring and evaluation}

\section{Key operational challenges}

\section{Number of} Beneficiaries

17. Budget performance

\section{Expected completion} date
Information is disseminated through presidential speeches; virtual conferences held by the Ministry of Finance; institutional portals and social media accounts at the Ministry of Labor and the Ministry of Finance; digital publications; discussion forums in the portal of the Ministry of Finance; and the creation of a web portal (http://fase.mt.gob.do/web/), two online consultation sections (https://www.hacienda.gob.do/consulta-afiliacion-fase/ and https://www.quedateencasa.gob.do/Default.aspx), jointly with QEC, and telephone query lines, (809-688-8838, 809-686-0092), jointly with PA' TI; as well as interviews and press releases in national newspapers.

FASE's monitoring and evaluation mechanisms are unknown.

Delays in fund disbursements were attributable to a series of adjustments to the system governing FASE's internal processes during the extension of the program, according to the Ministry of Finance.

A total of 905,857 workers employed by 51,572 companies (data reported as of July 13, 2020, by the Ministry of Finance).

DR\$20,162,554,518.39 (US\$353.2 million)

(data reported as of July 13, 2020, by the Ministry of Finance).

\section{II.2 Stay at Home (QEC)}

16. The government designed the QEC program to protect poor and vulnerable households from the negative economic impacts of the lockdown. Program beneficiaries are households participating in the conditional cash transfer (TMC, Spanish acronym) program PROSOLI, receiving the Comer es Primero (CEP, Spanish acronym) and Bonogas Hogar benefits. As QEC increases the size of the CEP transfer constitutes a vertical expansion of the program. The QEC program also increased the coverage, on an emergency temporarily basis, of the country cash transfers (horizontal expansion) adding vulnerable household, in addition to the existing poor households of the CEP and Bonogas benefits. The QEC program mitigates the potential economic impact of the pandemic on households by increasing the income of the poor and providing income support to the vulnerable.

17. QEC was not officially created by a presidential decree. The QEC program uses PROSOLI and the noncontributory social protection legal, administrative, and operational frameworks as well as the state of emergency and administrative acts. The noncontributory social protection system regulatory framework includes decrees establishing the Social Protection Program, PROSOLI, SIUBEN, the ADESS payment system, the GCPS (under the coordination of the Vice Presidency of the Republic), and other agencies implementing policies that affect the poor and vulnerable population. ${ }^{15}$. However, on May 26,

\footnotetext{
${ }^{15}$ These decrees include: (i) Decree № 1082-04 that establishes that the Vice-Presidency of the Republic shall chair the GCPS and ensure the consistency and coordination of all plans and programs formulated by participating agencies; (ii) Decree № 1554-04 that established the Social Protection Program to protect the extremely poor and socially vulnerable population from risks; (iii) Decree № 1073-04 that established SIUBEN, which is responsible for identifying families eligible to receive public benefits and subsidies; (iv) Decree № 1560-04 that established the
} 
2020, the Social Policy Coordination Cabinet (Gabinete de Coordinación de Políticas Sociales, GCPS) issued Administrative Resolution № 001-2020, which retroactively formalized the establishment of QEC and created its institutional implementation guidelines. The administrative resolution was a necessary step to guide and institutionalize the implementation of QEC.

18. The DR national COVID-19 response and the design of large emergency cash transfer programs such as the QEC program required strong institutional and coordination arrangements. For the national COVID-19 response plan, led by the Ministry of the Presidency and the Ministry of Finance, a series of high-level commissions with specific coordination arrangements were put in place. Decree № 132-20, created the High-Level Commission for the Prevention and Control of Coronavirus, the Economic Affairs Committee, and the Social Affairs Committee to support the development of the national COVID-19 response plan. On the social response side, the Vice Presidency, in charge of the GCPS, and the Ministry of Finance designed the QEC program. Key partners of the QEC program include: 1) SIUBEN, PROSOLI and ADESS; The Dominican Telecommunications Institute that provided contact information for new QEC beneficiaries; 2) the Treasury for Social Security (TSS, Spanish acronym) that supported the beneficiary selection process by providing data on the working status of eligible groups and; 3 ) the National Institute for the Protection of Consumer Rights that monitored local prices and conditions at stores that were part of the RAS (See figure 1).

19. Innovations and coordination with the private sector and other government agencies was a necessary step to streamline the QEC program processes. While the GCPS's institutions ${ }^{16}$ have a wellestablished delivery system, the massive increase in beneficiaries required additional coordination and innovations efforts. Innovations in the delivery of benefits include: (i) the development of new payments mechanisms such as digital payments and electronic transactions for new beneficiaries; (ii) the incorporation and training of new grocery stores and retail centers to the CCT Social Supply Network (RAS) to accommodate the excess of demand for the program. To comply with the increase on demand, over 2,000 new retailers, including large supermarkets, have been incorporated nationwide and trained and equipped with electronic payment devices; and (iii) the coordination of inventory and compliance with social-distancing measures at the RAS.

20. The QEC program beneficiaries were identified using the SIUBEN targeting and identification system. Targeting of social protection programs in DR is based on the Quality of Life Index (QLI) (Indice de Calidad de Vida, ICV), a multidimensional measurement of structural poverty, calculated using the proxy means test (PMT) methodology. Households and population are classified into four groups: QLI 1 multidimensional extreme poor; QLI 2 multidimensional moderate poor; QLI 3 multidimensional non-poor and vulnerable; and QLI 4 multidimensional non-poor and non-vulnerable. SIUBEN identify both regular CCT beneficiaries as well as new temporary beneficiaries. The QEC program includes households classified as poor or vulnerable according to SIUBEN's Quality of Life Index (QLI). SIUBEN also identify households

Administrator of Social Subsidies (Administradora de Subsidios Sociales, ADESS) as the unifying social-benefit payment body and set up the institutional and functional links with the GCPS and other government agencies responsible for determining, implementing, and targeting social subsidies; (v) Decree № 536-05 that established the Solidarity Program as a means to implement the poverty-reduction strategy, which includes conditional cash transfers to increase the income of, and human capital investments in, extremely poor families; (vi) Decree № 42607 that established SIUBEN to identify, categorize, register, and prioritize poor families living inside and outside areas identified in the Poverty Map; and (vii) Decree № 488-12 that establishes the Progresando con Solidaridad (PROSOLI) program by integrating and merging the Progresando and Solidaridad programs (which focused on building human and social capital) as part of the country's poverty-reduction and human-development strategy. 
with older adults or members who are especially vulnerable to COVID-19 as they receive an additional benefit. Additionally, the QEC program admitted an on-demand application process to a limited number of households. The Vice-presidency in its QEC web portal (https://quedateencasa.gob.do/) added a feature for an on-demand application form. Specific population groups asked to be included in the QEC program such as independent workers, vulnerable disabled persons, among others. At the end of April, on a public speech, the Vice-president announced that close to 1 million on-demand claims were received, and out of those, 70,000 new households were admitted to the program, mostly informal-sector workers, including beauticians, cab drivers, artisans, street vendors, among others. The on-demand applications were cross-checked with SIUBEN, TSS, and the FASE databases. PROSOLI has also an on-demand application process, using the one-stop customer service window, Punto Solidario, QEC beneficiaries could also use Punto Solidario.

21. The QEC program increased the transfer for the beneficiaries of the CEP and Bonogas benefits (Vertical Expansion) and provided income support to new beneficiaries (Horizontal Expansion). The size of the QEC transfer is DR\$5,000 (US\$87) monthly to beneficiary households. In the case of the $811,003^{17}$ households receiving the CEP and Bonogas benefits, the QEC program increase the size of their monthly transfer to more than six times the regular transfer of DR\$850 per month (US\$14.46). The horizontal expansion (new beneficiaries) include vulnerable households not included in Comer es Primero. Additionally, households with seniors over sixty-years-old or members with a health condition vulnerable to COVID-19 receive a top up transfer of DR\$7,000 (US\$122) per month. The QEC transfer amount represents $24 \%$ of the DR average income, and $33 \%$ when considering the top up benefit for vulnerable population. ${ }^{18}$ The benefit is also equivalent to just over 82 percent of the food and (non-alcoholic) beverage line in the basket of consumer goods for households in the first income quintile.

22. Due to significant increase of beneficiaries a new and innovative payment method was developed in partnership with financial and telecommunications companies. While the CEP program has a well-established payment system, the significant beneficiary increase of the QEC program require the social subsidy administrator (ADESS, Spanish acronym) to partner with several private and public sector institutions to develop an innovative digital payment system. Key partners include BANRESERVAS, Banco BHD-León, Asociación Cibao de Ahorros y Préstamos, Asociación La Nacional de Ahorros y Préstamos, CARDNET, VISANET, VISA Dominicana, and Evertech. Through this partnership, ADESS found expeditious ways to facilitate beneficiaries' transactions when purchasing food and other basic consumer goods while expanding business opportunities for these companies. ADESS also expanded its network retailers and stores (RAS) nationally to be able to cope with large demands. The expansion and strengthening of RAS

\footnotetext{
${ }^{17}$ There are issues related to the distribution of QEC households, as different sources and timelines report different figures. On April 2, 2020, the Vice-Presidency press release 899,354 PROSOLI households and 600,646 temporary household as the total number of QEC beneficiaries. The PROSOLI monitoring report includes figures closer to the 60-40 percent ratio claimed by the Vice-Presidency press release (https://super7fm.com/pais/vicepresidentaanuncia-casi-900-mil-familias-recibiran-subsidio-quedate-en-casa/). However, the president submitted a report to the Senate on July 10, 2020, stating that QEC has benefited more than 1,600,000 households, including 780,000 new households (pp.25).

18 UNDP 2020. The average income of workers according to the ENCFT in 2018 was RD \$22,145.4 (See table 5 of the UNDP work), therefore the transfer of $\operatorname{RD} \$ 5,000$ represents $22 \%$ and the transfer of $\operatorname{RD} \$ 7,000$ represents $31.6 \%$ of the average income of Workers. However, the quote refers to the average income of QEC beneficiary households which represents between $24 \%$ and $33 \%$, which is to be expected since they are households with lower income levels.
} 
retailers is having a ripple effect in the economy, favoring local production, microenterprises, farmers, and transportation as well as small local suppliers.

23. The QEC program leveraged on some of the monitoring tools of the CEP program, but could benefit from additional monitoring and evaluation procedures. The GCPS Technical Directorate, ADESS and PROSOLI use some of the CEP program monitoring tools for the QEC, such as a) ADESS' payment monitoring system that monitors, among other, the volume of transactions, the average number of transactions, and the use of funds; and b) PROSOLI Community Reports (participatory monitoring), which included more than forty-two PROSOLI beneficiary family groups (núcleos de familias solidarias) from the top-ten provinces with the highest concentration of extremely poor households nationwide. Additionally, PROSOLI conducted a two new telephone monitoring surveys, sampling 3,231 beneficiary households. PROSOLI reported that surveys results indicated that 99 percent of respondents rated the QEC program as a "good" or "very good".

24. Likewise, the QEC program leveraged on some of the grievance redress procedures of the CEP program but could benefit from additional social accountability procedures. The ADESS use PROSOLI's family school groups and the one-stop customer service window (Punto Solidario) to obtain program feedback. Additionally, ADESS put in place a new telephone-based grievance redress mechanism. Beneficiary feedback allowed for the timely adjustment of the QEC program payment mechanism. However, these adjustments were not enough, as different attempted scams required ADESS to implement a strategy for excluding non-compliant retailers and prosecute scammers. The QEC could benefit from strengthening the digital payments mechanism as well as its grievance redress procedures to prevent future fraudulent activity.

25. The QEC program used multiple tools in its communication strategy. Tools include presidential and vice-presidential speeches, social media, print media, radio, and television, as well as other digital media platforms. At the highest level, the President held several presidential addresses regarding the government response to the COVID-19, including key information of the QEC program. The Vice-president, as responsible of the noncontributory social protection system, also gave several speeches and interviews along with the directors of the GCPS, PROSOLI, SIUBEN and ADESS. Other communications tools include: 1) press releases: in national newspapers as well as institutional portals and social network sites of the Vice Presidency, ADESS, PROSOLI, SIUBEN, and the GCPS; 2) call center: ADESS used its call center to verify data on new beneficiaries and facilitate payments; 3) Text messages: ADESS sends beneficiary key information, including payment dates and retail information; 4) printed and digital instructional, informational, and promotional materials: RAS retail brochures, delivery of kits, guidelines on how to manage customers, prevent crowding in stores, facilitate transaction processes, among other key information for payments.; 5) Punto Solidario discussion forums; 6) dedicated websites: query portal to verify QEC affiliation; and 7) Toll-free numbers: for beneficiaries to obtain information on the program.

26. At the international organization level, the Adaptive Social Protection (ASP) Group, provided key feedback, guidance, technical assistance, and additional resources during the design and implementation of the social protection response. The ASP group was originally created to support the Government efforts in designing an adaptive social protection system. As part of this process, the World Bank and the United Nations agencies ${ }^{19}$, jointly with the government, developed a common working plan

\footnotetext{
19 Including the World Food Programme, UNDP, United Nations Children's Fund, United Nations Population Fund, International Organization for Migration, United Nations High Commissioner for Refugees, and the Food and Agriculture Organization.
} 
around adaptive social protection. When the COVID-19 crisis hit, the group was flexible enough to adequate part of its working plan to provide just-in-time technical assistance to the government. The ASP group provided feedback, guidance, technical assistance, and additional resources during the design and implementation of the QEC program. The ASP group holds by-weekly meetings and work sessions to continue its support to the government in the economic recovery plan and in designing and adaptive social protection system.

\section{Announcement March 25, 2020. date}

Stay Home (QEC)

2. Effectiveness

3. Regulatory instruments

4. Goal

5. Target population

6. Eligibility restrictions

7. Non-eligible populations

\section{Benefits}

From April through December 2020.

On May 26, 2020, the GCPS issued Administrative Resolution No. 001-2020, which retroactively formalized the establishment of the QEC program, as well created the institutional implementation guidelines. QEC was built on the existing legal, administrative, and operational social-protection framework.

Protect the income and food security of the most vulnerable households through a temporary unconditional cash transfer to counteract the negative economic effects of lockdown measures imposed to control the spread of COVID-19.

Poor and vulnerable households as defined by SIUBEN's QLI, with an emphasis on protecting households with members especially vulnerable to COVID-19, such as seniors over the age of sixty, people living with disabilities (PLWDs), and people living with HIV (PLWHs), tuberculosis, and/or cancer.

SIUBEN, the government's official social-protection targeting instrument, is used to determine eligibility based on household categorization criteria, including poverty and vulnerability.

In accordance with SIUBEN and QEC criteria, the following groups are non-eligible: undocumented heads of households or households not categorized as poor or vulnerable, according to the Quality of Life Index criteria.

- Vertical expansion of PROSOLI: The cash transfer provided to PROSOLI's Comer Es Primero beneficiaries increased from an average of $D R \$ 1,500$ to $D R \$ 5,000$ per month.

- Temporary horizontal expansion of PROSOLI: Households categorized as poor or vulnerable (QLI 1,2 and 3) in SIUBEN, as of 2018, including households currently not receiving PROSOLI benefits, receive a temporary cash transfer amounting to $\mathrm{DR} \$ 5,000$ per month.

- $\quad$ Supplemental Package for the most vulnerable: PROSOLI households with members especially vulnerable to COVID-19, including heads of households over sixty-years-old, PLWDs, PLWHs, and/or people with tuberculosis or cancer), are entitled to an additional DR\$2,000 per month, totaling DR\$7,000.

Cash transfers are used to purchase food (from a basket of consumer goods) in grocery stores, supermarkets, and other authorized retailers, according to their adherence to the government's Social Supply Network. 


\section{Frequency}

10. Implementing entities

11. Sources of information and key partners

12. Implementation arrangements

14. Monitoring and evaluation

15. Key operationa challenges

\section{Number of} beneficiaries
Monthly, paid every two weeks, different dates for PROSOLI's current and new beneficiaries.

PROSOLI and ADESS, led by the Vice-Presidency of the Republic.

- $\quad$ SIUBEN is the primary source of information for targeting beneficiaries.

- Key implementing partners are public- and private-sector actors, international organizations, and community participants.

In operational terms, the QEC program leverages the capacity and tools already existing at ADESS, PROSOLI, and SIUBEN. The activities required to implement the program are organized around five key crosscutting themes: beneficiary selection, payment system, communications, transaction mechanism, and monitoring and evaluation.

- Beneficiary selection: Beneficiaries are selected based on data from SIUBEN and checked against the TSS. To validate beneficiary data, new beneficiaries are contacted by phone or SMS, according to data available by INDOTEL, or via the virtual platform (www.quedateencasa.gob.do), which is also used to keep PROSOLI beneficiaries updated on changes to their benefits.

- Payment System: Supported by counterparts in the banking system, a new payment mechanism was introduced for new beneficiaries to make purchases by using their identification cards. The RAS was expanded and strengthened with 2,000 new retailers. To generate payments, the QEC payroll process was integrated as another component of PROSOLI and ADESS' recurrent operations, supported by the existing and successful payment platform created in 2005. QEC contributions are credited directly to the beneficiaries' cards or accounts.

- Communications: Digital, print, social media, radio, and television strategies have been used to inform the population about the program.

- Monitoring and evaluation: ADESS, PROSOLI, and the GCPS Technical Directorate have different monitoring and evaluation mechanisms to monitor program implementation and follow up on results (See details in section 14).

Various mechanisms were used to monitor QEC, including ADESS' capacity to quantitatively monitor the payment system and qualitative instruments by PROSOLI and the GPCS. Results from monitoring surveys revealed that 99 percent of the respondents rated the QEC program as "good" or "very good."

- $\quad$ Some initial setbacks in contacting representatives of beneficiary households.

- Nearly one million applications to QEC revealed coverage gaps and required greater beneficiary selection and integration efforts.

- Continuous need to implement several strategies to address crowding in stores.

- Different attempted scams and fraud schemes against the benefit payment system required $A D E S S$ to implement a strategy for excluding non-compliant retailers and prosecuting fraudsters or scammers.

- $\quad$ SMS communication demanded resources that were often lacking.

In June 2020, PROSOLI stated that QEC supports some 1,570,000 households, including 60 percent of PROSOLI households who make their purchases with the benefits card, with the remaining 40 percent made up of vulnerable households who were not previously enrolled in the Social Protection Network. 

17. Budget
performance
18. Expected December 31, 2020.
completion date
Source: Author.

DR\$ 14,967.8 million, as of June 2020.

\section{II.3 Independent Worker Assistance Program (PA' TI)}

27. The Ministry of Finance implements and manages the PA' TI Program. Decree № 185-20 mandates that the Ministry of Finance ( $\mathrm{MH}$ Spanish acronym) manages the PA' TI program, in collaboration with other public and private institutions. The $\mathrm{MH}$ developed a new cash transfer management platform to deliver benefits to its target population and linked it to the banking system. To implement the PA' TI, the Ministry of Finance appointed a technical team made up of a developer, a business manager, and a development manager.

28. The PA'TI program had, in addition to the predeterminate accessibility list, an on-demand selfinclusion identification option. The $\mathrm{MH}$ created a web portal (https://pati.hacienda.gob.do/buscar) where people could check whether they were eligible for the benefit or not by inserting their ID number. Beneficiaries could also use the web portal to edit their information in case of errors or inconsistencies. Additionally, the web portal featured an on-demand application that independent workers could use to apply to the program. When found eligible, program representatives would contact applicants to inform them on the approval of the benefit. ${ }^{20}$ Once the final list of potential beneficiaries was ready, the $\mathrm{MH}$ cross-checked the data with other administrative databases such as the databases from the SIB and other public institutions administering financing programs in which eligible self-employed workers participate. Finally, the $\mathrm{MH}$ issued the final payment list and informed the financial institutions and the beneficiary (when his/her information was available). As of July, 2020, a total of 3,560,797 queries were registered in the program portal, the program had 189,767 beneficiaries, and a total of 65,809 on-demand applications were received, of which only 3,069 applications were approved (the rest were rejected).

29. The PA' TI program targets am important and large vulnerable group affected by the COVID-19 crisis, the self-employed or independent workers. The program was announced on May 17, 2020, when the magnitude of the economic downturn and the hardships faced by self-employed workers under the mobility restrictions was evident. Independent workers are particularly vulnerable to effects of the crisis as they usually lack social protection. The PA' TI program was designed to provide income support to independent workers to alleviate the economic effects of the crisis. The program provides an emergency temporarily cash transfer of RD\$5,000 (US\$90.2). Beneficiaries must have a valid identification document and demonstrate that, on or after February 29, 2020, they had a loan with a financial institution under the supervision of the Superintendence of Banks (SIB Spanish acronym), or with a central government financing program. Beneficiaries are ineligible to participate in the program if they: (i) contribute to social security, (ii) already receive FASE or QEC, (iii) own a large enterprise, or (iv) paid annual taxes exceeding RD\$150,000 (US\$2,705). Under the established eligibility criteria, the MH announced on May 19, 2020, that roughly 202,405 eligible self-employed workers had been identified.

\footnotetext{
${ }^{20}$ Details on the on-demand application approval process are not available.
} 
30. The PA' TI program required building multi-stakeholder alliances, especially for identification of beneficiaries and delivering of payments. The identification of eligible self-employed workers required unprecedented cross-reference of data among multiple stakeholders. To conduct the cross-reference, the $\mathrm{MH}$ had to overcome legal hurdles associated with tax and banking secrecy. The institutions involve in cross reference of the data include the SIB; the Government's program for credit for low-income entrepreneurs Banca Solidaria; the Vice-Ministry for MSME Development under the Ministry of Industry, Commerce and SMEs; the TSS, the Dominican Internal Revenue Service (Dirección General de Impuestos Internos, DGII), the Ministry of Labor; ADESS; BANRESERVAS; and other financial institutions.

31. Like the QEC and FASE programs, the MH created a dedicated website for the self-registering of beneficiaries of the PA'TI program. On June 3, 2020, MH launched the PA'TI dedicated website where people could check if they were eligible to participate in the program. ${ }^{21}$ The Ministry of Finance authorizes payments and transfers them through the Governmental Integrated Financial Management System to the beneficiaries' accounts at the relevant financial institution (15 percent of beneficiaries, who were linked to cooperatives, had to open accounts at BANRESERVAS).

32. While there is an internal monitoring system, there is very limited external public information on program performance. There is very limited external data on the number of beneficiaries, funds disbursed, and the socio-economic characteristics of the target population, information available for QEC and FASE and the regular national social programs. There is key contact information from beneficiaries missing such as phone or e-mail. This contact information has been key for the identification and payment of the FASE and QEC benefits. Even though Decree № 185-20 instructs the MH to inform beneficiaries when cash transfers are paid, there are no practical plans or mechanisms to contact beneficiaries. Beneficiaries are required to be proactive and contact the $\mathrm{MH}$ to confirm they are receiving benefits.

Self-Employment Assistance Program (PA' TI)

1. Announcement date May 17, 2020.

2. Effectiveness

From May through December 2020.

3. Regulatory instruments

Decree № 185-20, dated May 29, 2020 (establishment); Decree № 242-20, dated July 8, 2020 (extension to August 16); and Decree № 358-20 (extension to December).

4. Goal

Support eligible self-employed workers with a temporary unconditional cash transfer to counteract the negative economic effects of lockdown measures taken to control the spread of COVID-19.

5. Target population Self-employed workers with a credit line in the formal sector.

\footnotetext{
${ }^{21}$ https://pati.hacienda.gob.do/buscar.
} 


\section{Self-Employment Assistance Program (PA' TI)}

6. Eligibility restrictions

7. Non-eligible

Populations

8. Benefits

9. Frequency

10. Implementing entity

11. Sources of information and key partners

12. Implementation arrangements

13. Communication strategies

14. Monitoring and evaluation

15. Key operational challenges

16. Number of beneficiaries

17. Budget performance
PA' TI beneficiaries must have a valid ID document and demonstrate that on or after February 29, 2020, they had taken out a loan with a financial institution governed by the SIB, or with a central government-administered financing program.

Self-employed workers are ineligible to participate in the program if they:

1. contribute to social security as of February 29, 2020;

2. receive benefits from QEC or FASE;

3. are classified as a local or national large enterprise, if they filed taxes with the DGII; or

4. Their tax return payments exceed $D R \$ 150,000$ in one fiscal year, if they filed taxes with the DGII.

Informal self-employed workers, FASE and QEC beneficiaries, and workers without ID documents.

$\mathrm{DR} \$ 5,000$ in unconditional cash transfers, subject to no tax withholding.

Monthly.

Ministry of Finance.

SIB; Banca Solidaria under the Program of the National Council for the Promotion and support of the Micro, Small and Medium-sized Enterprise (PROMIPYME); Vice-Ministry for MSME Development under the Ministry of Industry, Commerce and SMEs; TSS; DGII; Ministry of Labor; ADESS, and BANRESERVAS.

The Ministry of Finance and key partners cross-check information, verify eligibility, and process benefit payments. Beneficiaries can use the portal at the Ministry of Finance (https://pati.hacienda.gob.do/) to confirm their participation or apply for benefits.

Information is disseminated through presidential speeches; virtual conferences held by the Ministry of Finance; institutional portals and social media accounts at the Ministry of Finance and MIMC; discussion forums on the portal of the Ministry of Finance (https://pati.hacienda.gob.do/); email (pati@hacienda.gov.do) and telephone (809-686-0092) support (jointly with FASE); and interviews and press releases in national newspapers.

An internal monitoring dashboard is used for monitoring and evaluation activities.

Limited beneficiary information, especially contact information and outdated bank records, that delay the transfer of benefits.

189,864 beneficiaries, as of July 15, 2020.

RD\$1,834 million, as of June 2020. 


\section{Self-Employment Assistance Program (PA' TI)}

18. Expected completion December 31, 2020.

date

Source: Developed by the author based on a desk review. 


\section{Social Protection Expenditure and poverty mitigation of the three emergency cash transfer programs}

33. During the first three months of the pandemic, the cost of the three cash transfer programs was 0.76 percent of GDP. By December 2020, this cost will increase to roughly 2.75 percent of GDP. To finance the COVID-19 response, the government modified the national budget in June of 2020 (Law № 64-20) to account for an expected 14.3 percent reduction of public revenues and the need to create fiscal space for pandemic-related healthcare expenses. Between April-June 2020, COVID-19-related expenditures amounted to US\$731.2 million representing 0.92 percent of GDP. The three emergency cash transfer programs represent 83 percent of all COVID-19 related expenditures in Apr-Jun 2020. When adding other social programs such as the School Feeding Program, the Social Assistance Plan of the Presidency and Comedores Económicos del Estado Dominicano, social protection expenditures represented 90 percent of all public spending to mitigate the effects of the pandemic. Spending on cash transfers between April and December 2020 is projected to reach US\$2,188.3 million ${ }^{22}$ (Table 4).

34. The monthly transfer of the QEC, PA'TI and FASE programs is lower than the monthly worldwide cash transfer average, but its duration and coverage is higher. The QEC and PA'TI's monthly transfer is US\$88.23 23,24 , equivalent to $46.6 \%$ of the minimum wage in the private sector ${ }^{25}$ and $12.3 \%$ of the monthly GDP per capita of 2019. The monthly average, out of 95 countries, of the emergency cash transfers represent $26 \%$ of the monthly GDP per capita. However, the average duration of cash transfers globally is 3.3 months, while in the Dominican Republic the programs duration is 9 months ${ }^{26}$. The Dominican Republic was among the top 15 countries, out of 84 , with the highest population coverage of social assistance programs associated with COVID-19, with a coverage of $53 \%$ of the population, more than triple the global average of $17 \%{ }^{27}$ and much higher than the $10 \%$ average estimated for the Latin America and the Caribbean region. ${ }^{28}$

\footnotetext{
${ }^{22}$ Assuming a projection of cash transfers associated to COVID-19 equivalent to RD $\$ 123,603.1$ and an average exchange rate of RD\$56.4849 per US\$ during 2020.

${ }^{23}$ The monthly payment for Stay at Home and Pa'ti is RD $\$ 5,000$, which at the average dollar exchange rate of the March-September 2020 period of RD $\$ 56,664$, corresponds to US $\$ 88.23$. This amount also corresponds to the minimum payment received by the FASE beneficiary.

${ }^{24}$ The monthly payment for Stay at Home and Pa'ti is $\operatorname{RD} \$ 5,000$, which at the average dollar exchange rate of the March-September 2020 period of RD $\$ 56,664$, corresponds to US $\$ 88.23$. This amount also corresponds to the minimum payment received by the FASE beneficiary.

25 The minimum wage in the non-sectorized private sector depends on the size of the company, the lowest of which is equivalent to RD $\$ 10,730$ per month (US $\$ 189.36$ at the average exchange rate of RD $\$ 56,664$ from March-September 2020). Similarly, the 2019 monthly per capita GDP was US \$715.25)..

${ }^{26}$ Programs will be in effect from April to December 2020.

${ }^{27}$ Gentilini et al. (2020). Social Protection and Jobs Responses to COVID-19: A Real-Time Review of Country Measures. "Living paper" version 13 (September 18, 2020), World Bank. Pages 4-6.

${ }^{28}$ UNDP, $2020 \mathrm{~b}$.
} 
Table 4. Budgeted vs Actual Social Protection Expenditure Related to COVID-19, Apr-Dec 2020

\begin{tabular}{|c|c|c|c|c|c|c|c|c|c|c|c|c|}
\hline \multirow[t]{3}{*}{ Expenditure Item } & \multicolumn{5}{|c|}{ Budgeted Expenditure 2020} & \multicolumn{5}{|c|}{ Actual Expenditure Apr-Jun } & \multicolumn{2}{|c|}{$\begin{array}{l}\text { Projection Apr- } \\
\text { Dec } 2020\end{array}$} \\
\hline & \multicolumn{2}{|c|}{ Million } & \multicolumn{3}{|c|}{ Percentage } & \multicolumn{2}{|c|}{ Million } & \multicolumn{3}{|c|}{ Percentage } & \multirow[t]{2}{*}{ RD\$ } & \multirow{2}{*}{$\begin{array}{l}2020^{*} \\
\text { GDP }\end{array}$} \\
\hline & $\mathrm{RD} \$$ & US\$ & $\begin{array}{l}\text { Total } \\
\text { Covid }\end{array}$ & \begin{tabular}{|c|} 
Total \\
expend \\
-iture
\end{tabular} & $\begin{array}{c}2020^{*} \\
\text { GDP }\end{array}$ & $\mathrm{RD} \$$ & US\$ & $\%$ & $\begin{array}{c}\text { Total } \\
\text { expend } \\
\text {-iture }\end{array}$ & $\begin{array}{l}2020^{*} \\
\text { GDP }\end{array}$ & & \\
\hline Cash transfers & $42,979.8$ & 759.1 & 66.8 & 4.7 & 0.96 & $34,180.2$ & 603.7 & 82.6 & 3.8 & 0.76 & $123,603.1$ & 2.75 \\
\hline QEC Program & $22,779.8$ & 402.3 & 35.4 & 2.5 & 0.51 & $14,967.8$ & 264.3 & 36.2 & 1.7 & 0.33 & $66,554.4$ & 1.48 \\
\hline FASE Program & $17,200.0$ & 303.8 & 26.7 & 1.9 & 0.38 & $17,378.4$ & 306.9 & 42.0 & 1.9 & 0.39 & $49,848.5$ & 1,11 \\
\hline PA'TI Program & $3,000.0$ & 53.0 & 4.7 & 0.3 & 0.07 & $1,834.0$ & 32.4 & 4.4 & 0.2 & 0.04 & $6,397.9$ & 0.16 \\
\hline Ministry of Health & $12,348.0$ & 218.1 & 19.2 & 1.4 & 0.28 & $2,490.8$ & 44.0 & 6.0 & 0.3 & 0.06 & & \\
\hline $\begin{array}{l}\text { School Feeding } \\
\text { Program }\end{array}$ & $4,561.0$ & 80.6 & 7.1 & 0.5 & 0.1 & $3,181.5$ & 56.2 & 7.7 & 0.4 & 0.07 & & \\
\hline $\begin{array}{l}\text { Incentives for } \\
\text { Humanitarian Action }\end{array}$ & $1,958.9$ & 34.6 & 3.0 & 0.2 & 0.04 & $1,303.8$ & 23.0 & 3.1 & 0.1 & 0.03 & & \\
\hline Others & $2,482.0$ & 43.8 & 3.9 & 0.3 & 0.06 & 243.0 & 4.3 & 0.6 & 0.0 & 0.01 & & \\
\hline TOTAL & $64,329.7$ & $1,136.1$ & 100.0 & 7.1 & 1.43 & $41,399.4$ & 731.2 & 100.0 & 4.6 & 0.92 & & \\
\hline
\end{tabular}

Source: Author's estimates based on data from DIGEPRES and MEPyD.

Note: National Budget Law № 64-20: RD\$906,702.9 million, official projection of nominal of GDP in 2020: RD\$4,489,239.3. April-Jun 2020 Average USD Exchange Rate: 56.6215.

Projection Abr-Dec for FASE and QEC is the sum of actual expenditure in Apr-Nov for FASE (RD\$43,458.5 mill) and QEC (RD\$60,655.3 mill) and projection of expenditure in Dec as the same level of actual expenditure in Nov plus $\mathrm{RD} \$ 2,300$ mill corresponding to Christmas bonus for FASE I beneficiaries, based on the decision of Decree 685-20

16. The three government emergency cash transfer response programs have mitigated the crisis negative effects on poverty. But their mitigation effects will depend on the duration of the crisis and of the programs and the speed of the recovery of the economy. The three programs QEC, FASE and PA'TI mitigated the poverty increase in the DR by 7.3 percentage points, 4.2 percentage points corresponding to the moderate poverty rate and 3.1 percentage points corresponding the extreme poverty ${ }^{29}$.The total impact on the annual poverty rate is linked to the duration of the crisis, the speed of the economy reactivation, and the duration of the three cash transfer programs. Given the temporary drop in labor income, a fraction of households may have used assets to avoid the drop in their consumption that affect their ability to recover or facilitate their upward economic mobility in the future.

${ }^{29}$ MEPyD (2020). Pages 8 and 9. 


\section{Lessons Learned}

\section{IV.1 Government Agility and Flexibility in the Pandemic Response}

35. A well-established noncontributory social protection system allowed the government to swiftly address the socioeconomic impact of the COVID-19 pandemic. The DR has a well-established delivery system for its main cash transfer programs to address the needs of the structural poverty. However, the COVID-19 crisis proved that there are a very large number of vulnerable, poor or non-poor people, often informal sector workers, often women, often urban, whose livelihoods were adversely affected by the COVID-19 crisis. The Dominican Republic Government swiftly put in place three innovative programs for low income formal workers (FASE), independent workers (PA' $\mathrm{TI}$ ) as well as vulnerable informal workers (QEC) to cover the vulnerable population, in addition to the poor, to address the socioeconomic impact of the COVID-19 pandemic, reaching outstanding levels of coverage. The three programs leverage the delivery system as well as existing inter-institutional coordination mechanisms of the Social Protection Program, which has been in operation since 2005, to quickly expand coverage and benefits. Moreover, in the case of FASE and PA' TI, the government increase the capacity of the Ministry of Finance and the Ministry of Labor to enable a new cash-transfer management platform for vulnerable groups, as well as to build new partnerships to identify eligible beneficiaries and deliver payments.

36. New Inter-institutional and inter-sectoral collaboration, as well as public-private partnerships (PPPs), were key to deliver the emergency cash transfer programs. Inter-sectoral collaboration and PPPs have been instrumental to identify beneficiaries and to establish payment and monitoring systems. The government design coordination arrangements at the highest levels such as the high-level commission to develop the COVID-19 response plan to create synergies among government agencies to effectively response to the COVID-19 crisis. Different agreements were put in place to facilitate information sharing and system interoperability to ensure the effectiveness of social protection programs. Moreover, the implementation of QEC would not have been possible without the collaboration of RAS retailers and the banking sector. Parentships with the private sector firms facilitated the processing of FASE applications in favor of affected workers.

\section{IV.2 Coverage Gaps and Underserved Populations}

37. Despite efforts to ensure that programs complemented each other and covered poor and vulnerable households, important gaps and challenges remain that could exacerbate pre-existing inequalities. Potential beneficiaries are often required to demonstrate some degree of formalization linked to tax, financial or social security records. Both the FASE and the PA'TI programs excluded informal sector workers. The PA'TI program requires potential beneficiaries to show records of loans in the formal credit system, leaving out many self-employed workers. According to GlobalFindex, ${ }^{30} 44$ percent of the Dominican adult population did not have a bank account in 2017, which rises to 58 percent for the bottom 40 percent of the adult population. Self-employed workers in the agriculture sector are also likely underrepresented among PA' TI beneficiaries, as the Agricultural Bank (Banco Agrícola) was not involved in the process of identifying potential beneficiaries. For FASE, only formal companies up to date with their social security contributions can join the program. However, according to the 2018 ENCFT, only 50 percent of workers reported being employed by a company register in the National Taxpayers' Registry, which implies that the social security contribution requirement leaves a large share of workers ineligible to

${ }^{30}$ https://globalfindex.worldbank.org/. 
participate in FASE. Initially, FASE was more restricted as it targeted formal workers in non-essential sectors, but this was amended with FASE 2, as companies in essential sectors also face lower demand for their products and services. Finally, targeting firms and not workers restricted the inclusion criteria for FASE. Some analysts argue that it is unfair that workers are automatically excluded because they work for an informal companies or a company that failed to pay its social security contributions. ${ }^{31}$

38. The crisis has exposed the extreme vulnerability of informal workers, who account for most workers in the country and who are disproportionately impacted by the decline in work associated with the government COVID-19 responses. In 2018, most self-employed workers were not register in the National Taxpayer Registry, 15 percent of them were poor (260,727 workers) and 37 percent were poor or vulnerable (650,980 workers). ${ }^{32}$ Hence the 202,000 workers identified as eligible for the PA' TI program indicate a low coverage of the vulnerable self-employed workers. It is important to note that some of the vulnerable self-employed workers may have been covered by the QEC program. But cross-checks have not been conducted. UNDP estimates that a large share of households above the vulnerability threshold (not served by the QEC program) have members working in the informal sector, 54 percent have at least one informal worker, and 35 percent of the households have all their members working in the informal economy. ${ }^{33}$ The high incidence of informality makes these households vulnerable to the effects of the COVID-19 crisis, as informal self-employed workers: (i) are more likely to work in sectors hit hard by the lockdown, including construction, transportation and storage, and other services sectors; (ii) usually earn lower salaries than formal workers; and (iii) are more likely to live in poor or vulnerable households. ${ }^{34}$

39. Many undocumented individuals are not covered by the country's safety nets. Holding an identification document (ID) is a prerequisite to participate in the country's main cash transfer programs as well as in the three new emergency cash transfer programs. According to the 2018 National MultiPurpose Household Survey (Encuesta Nacional de Hogares de Propósitos Múltiples), 6.7 percent of the population aged fifteen or older does not have an ID, increasing to 14.9 percent for very low-income individuals. Undocumented individuals had fewer or not tools at all to mitigate the economic effects of the pandemic.

\section{IV.3 The Pandemic Underscored the Need for an Adaptive Social Protection System}

40. The pandemic highlighted the need for an adaptive social protection system that protects and increase the resilience of vulnerable groups against covariate shocks. Social protection programs with more comprehensive eligibility criteria, delivery instruments, and forms of financing would allow policy makers to better plan the country's response to covariate shocks and protect vulnerable groups. The Government of the Philippines established an ASP platform to respond with cash transfers to adverse weather shocks, allowing for a significant COVID-19 response that covered $78 \%$ of the population ${ }^{35}$. The new administration is expected to include all the elements of an adaptive social protection system as part of the noncontributory social protection system institutional reform. An adaptive social protection system aims to provide prioritized access to an integrated bundle of programs, systems, and services that

${ }^{31}$ http://library.fes.de/pdf-files/bueros/fescaribe/16183.pdf.

32 UNDP. 2020a. "Analysis of the economic impact of COVID by using 2018 ENCFT information." https://www.do.undp.org/content/dominican republic/es/home/library/impacto-economico-y-social-delcoviarad-19-y-opciones-de-politica-e.html.

33 UNDP 2020a.

${ }^{34}$ UNDP 2020a.

${ }^{35}$ Gentilini et al. (2020). Social Protection and Jobs Responses to COVID-19: A Real-Time Review of Country Measures. 
contribute to increasing the resilience of poor and vulnerable populations to natural, socio-natural, and man-made disasters. An ASP system will also institutionalize coordination arrangements within the NonContributory Social Protection System and with the National System for Disaster Prevention, Mitigation, and Response, increasing synergies and efforts to eliminate duplications.

41. SIUBEN needs to migrate to a universal and more flexible national identification social registry. As the country's key multidimensional poverty targeting tool, SIUBEN could advance to become the unified national social registry, used to select beneficiaries of all public social protection programs in the DR. For that, SIUBEN needs to include socioeconomic variables of all Dominican households. Likewise, it should be able to assess the impact of temporary shocks that change households' levels of monetary poverty or vulnerability to allow for timely information to effectively guide the social response to emergencies. A unified beneficiary registry would improve the effectiveness, efficiency, and timeliness of public spending. The key steps for the migration of SIUBEN towards a unified social beneficiary registry are:

- Improving the interoperability capacity of SIUBEN: SIUBEN needs to develop the institutional arrangements, instruments, and protocols with the mechanisms, and procedures to enable interoperability with other administrative public databases for timely decision-making. Linking SIUBEN with other public administrative databases will allow the registry to identify potentially marginalized and vulnerable groups in need of social assistance and to monitor their changing status. It will also allow SIUBEN to have updated information on households by accessing data from other existing databases and perform new analyses on social conditions, in addition to regular surveys to capture information not included in administrative records. Information should be accessed timely, be reliable, as well as ensure security and privacy of personal and sensitive data, among other considerations.

- Improve SIUBEN's capacity to capture temporary changes in poverty: SIUBEN could develop mechanisms to capture key data on temporary changes in poverty or vulnerability generated by external shocks, including climate, economic, and health-related events. SIUBEN includes data on structural poverty, which limits its use in emergencies to understand how events are affecting household income and which households are at risk of temporarily falling into monetary poverty. One option used by some countries for both pre-COVID shocks and during COVID is high frequency supplementary surveys as a means of quickly assessing potential eligibility for shock-related transfers.

- Strengthen the on-demand data collection services: Data will never reflect the situation at the onset of a crisis but the more up to date the better chances to reach all the poor and vulnerable. On-demand approaches to data collection are more flexible and have proven to be a useful strategy to complement non-universal data registries in many countries during the pandemic ${ }^{36}$. For example, the on-demand approach to the QEC program helped to promptly update the SIUBEN registry to identify

\footnotetext{
${ }^{36}$ The analysis presented by UNDP, 2020b highlights how other several Caribbean countries like the Bahamas, Barbados, Saint Kitts and Nevis, and Trinidad and Tobago also capitalized on electronic tools such as emails and internet platforms such that people could submit their information and be assessed for eligibility to social programs for pandemic relief. Likewise, some South American countries like Argentina, Brazil, Chile, Paraguay, Peru and Uruguay also established online platforms and telephone query lines such that people could request access to programs. Brazil, also included a walk-in service mechanism for on-demand claims of support by excluded individuals. In total, through all the means of on-demand access deployed, Brazil received and evaluated 96 million requests by the end of May 2020, of which 61\% were approved.
} 
key excluded populations in need in the crisis context. The DR should use the lessons learnt from its own on-demand approaches for the three emergency cash transfer programs, as well as best practices implemented in the region. Additionally, another key opportunity to make data collection efforts more flexible and timelier is to strengthen the scope and capacities of the on-demand process already in place through Punto Solidario .

- Institutionalize SIUBEN's mandate: There are legal restrictions on the use of existing databases to build profiles of potential social protection beneficiaries in times of emergency. Such provisions include protection of personal data such as data from banks, ${ }^{37}$ tax administration reserves, ${ }^{38}$ and social security. It is necessary to develop a legal framework to use SIUBEN as the unified social beneficiary registry and the unified targeting system for the eligibility and selection of beneficiaries for all public social protection programs. The legal mandate should enable SIUBEN to access information from all institutions that are part of the interoperability mechanism.

- Provide access to beneficiary data for policy design: Policy makers need to have comprehensive data on the number of, and how often households access, existing social protection programs (e.g., in-kind and health programs) to design emergency social response programs. Access to data will prevent redundancy and ensure value for money that increases inclusion of underserve populations.

42. Emergency programs need to have in place a comprehensive monitoring and evaluation system. Monitoring of results as well measuring outcomes and impact of social protection emergency programs devised to mitigate the socioeconomic effects of the pandemic will inform and improve the country's national social policies and programs. Measuring the outcomes and impact of public programs is important to assess progress systematically and objectively toward established goals and targets and collect evidence on policy effectiveness. The periodic disclosure of reports that systematically document the evolution of social protection programs will help to keep citizens informed of the country's social policies. The public disclosure of this type of information could increase accountability and ensure the public is informed of the progress and challenges around these programs.

43. Operations manuals are necessary to guide emergency program procedures and operating rules. Operations manuals for the QEC, FASE, and PA' TI programs would allow the authorities to clarify what, how, when, and where resources are used to reach program goals and targets. Manuals and operational procedures would also help identify opportunities to further improve current procedures to optimize program management and achieve greater technical and administrative efficiency. Operations manuals are also a useful instrument to facilitate the effective integration of new partners, and they constitute a valuable input for internal or external evaluators and auditors. The manuals need to document policies, strategies, standards, to inform the design of future programs.

44. Existing social protection programs need to be more flexible. The QEC program restricted the types of goods beneficiaries could purchase to mostly food items in line with the operational rules of the PROSOLI program. Though restrictions on the purchase of female hygiene products have been lifted, there

\footnotetext{
${ }^{37}$ The Article 56 of the DR Monetary and Financial Act № 183-02 (LMF) establishes thereof that financial institutions are obliged to "keep confidential information on deposits taken from the public, in a disaggregated manner that may disclose the identity of the person.

${ }^{38}$ Article 47 of the Tax Code Act № 11-92 states that tax returns and information submitted to the DGII by taxpayers, responsible parties and third parties by any means in principle shall remain confidential, and said information may be used for its own purposes, as required by law.
} 
are additional goods such as cleaning products and medicines that beneficiaries have urgently needed due to nature of the emergency. As such, an emergency cash transfer program such as QEC could benefit from flexibility on the types of goods that beneficiaries are allowed to purchase.

\section{IV.4 Synergies in Using Existing Capacity}

45. While public institutions have made progress in coordinating their efforts to identify beneficiaries and deliver benefits, more can be done to ensure the interoperability of systems and sharing of information and best practices. For example, PA'TI could have benefited from greater interoperability with SIUBEN, as the program's tax-payment ceiling requirement means that some of its beneficiaries are classified as QLI 3 or QLI 4. Similarly, ADESS' experience with cash-transfer payment systems could have been leveraged instead of building new systems at the Ministry of Finance. Closer coordination could have facilitated the sharing of best practices and the exchange of proven strategies to address known challenges. Also, beneficiaries would have benefited from a single web portal to access the QEC, FASE, and PA' TI programs.

46. A more comprehensive data-collection approach is also needed to better understand the needs of current beneficiaries, identify underserved populations, and develop evidence-based public policies. There have been proposals to systematize the information provided by denied applicants to allow the authorities to cross-check data, detect possible exclusion errors, and better understand the needs of beneficiaries. ${ }^{39}$ To this end, policymakers should consider systematizing the beneficiary records under Comedores Económicos, the Social Assistance Plan of the Presidency (Plan de Asistencia Social de la Presidencia, PASP), the Ministry of Education School Feeding Program, and other assistance programs and linking them to the beneficiary databases of QEC, FASE, and PA' TI. This could help to avoid duplication and optimize the targeting of assistance and resource investment. For example, PROSOLI's monitoring surveys revealed that of the households that receive cash transfers under the QEC program, 26.8 percent of also received food rations from the School Feeding Program, 11.5 percent received food rations from the PASP, 3.6 percent received aid from FASE, 1.4 percent received prepared meals from Comedores Económicos, 1.3 percent received food rations from social programs aimed at children, 1.2 percent received benefits from social programs aimed at the elderly, and close to 1 percent received benefits from the Presidency's Special Programs Directorate (Dirección General de Programas Especiales de la Presidencia, DIGEPEP). In addition, some UN agencies have proposed linking their databases, or those of related civil-society organizations, to the social programs' databases (e.g. data on migrants, refugees, stateless persons and other underserved groups). To date, however, only the QEC program has analyzed the socioeconomic characteristics of its target population. ${ }^{40}$

\footnotetext{
${ }^{39}$ The exclusion of some populations from the QEC, FASE, and PA' TI programs has been criticized by the affected groups. For example, the National Federation of Dominican Micro, Small and Medium-Sized Entrepreneurs (FENAPYMED) complained in June that many formal and informal MSMEs and self-employed workers feel they have been disenfranchised by FASE and PA' TI. They reported being enrolled in so-called "listings," but when they showed up at the bank they were not listed, or the funds promised were never deposited.

${ }^{40}$ PROSOLI reports that, according to QLI-based poverty levels, the QEC beneficiary population is distributed as follows: 17.8 percent are classified as QLI I, 63.5 percent are QLI II, 16.7 percent are QLI III, and 2 percent are informal-sector workers. Of the total households covered by QEC, 58 percent have female heads of household; 35 percent are headed by older adults; 7 percent are vulnerable due to some pre-existing health condition susceptible to COVID-19; 18 percent have children under the age of 5; and 39 percent of households have school-age children or adolescents (aged 5-21). In addition, 85 percent of QEC households have three members or more, estimated by the number of household members, which improves the scope of this cash-transfer program. In addition, the UNDP
} 


\section{IV.5 Need for an Exit Strategy}

47. A clear exit strategy is needed to move from acute crisis response to recovery. This means moving from emergency cash transfers to restart the livelihoods of individuals and households impacted by lockdowns and other measures. The three emergency cash transfer programs have been extended until December. The total social assistance estimated spending in 2020 is $2.75 \%$ of GDP, 1.13 percentage points higher than the spending in 2018. Worker unions and business organizations ${ }^{41}$ have asked the government gradually decrease the coverage of the cash transfer programs related to COVID-19, taking under consideration the speed of the economy and employment recovery. It is clear that social protection programs and policies need to be part of the government economic recovery plan to protect those households that take the longest to regain their pre-pandemic livelihoods. The pandemic highlighted the need for an integrated and systemic approach for a stronger integration of social protection programs with labor and economic inclusion policies, aimed at increasing resilience of livelihoods and income security. The government will need to create fiscal space to finance its recovery plan.

48. The new social protection reform announced by the new administration represents an opportunity to advance to a well-established social protection system. The elements of a wellestablished $^{42}$ social protection systems at the institutional level are well-defined institutional arrangements, supported by policy and legislation; an adequate mix of preventive, promotive and protective social programs and formalized coordination arrangements. The COVID-19 crisis has highlighted the urgent need for strong institutional arrangements at the policy and legislation levels as well as to increase the programs options for the poor and vulnerable. In terms of the delivery systems, a well-established social protection system has programs with high coverage relative to the target population (poor and vulnerable). Adequate benefits, supporting effective consumption smoothing and poverty reduction; minimal exclusion and inclusion errors; a variety of benefit options in place that facilitate choice and adaptation to different contexts; an integrated social registry to support social programs, covering a large segment of potential beneficiaries or total population; and integrated beneficiary registry facilitating cross-checks with other beneficiary registers; interoperable and integrated information systems; and sound M\&E system in place. In terms of the financing arrangements a wellestablished social protection system have reliable and sustainable financing for its social programs. A cross-cutting theme is to have its social protection system adaptive and flexible to help households prepare, cope, and adapt to shocks including disasters, pandemics and economic shocks.

estimates that among poor and vulnerable households receiving QEC benefits, 49 percent have at least one member who works in the informal sector, and 39 percent have all their members working in the informal sector.

${ }^{41}$ https://noticiassin.com/piden-extender-fase-hasta-primer-trimestre-de-2021/

https://noticiassin.com/piden-extender-fase-hasta-primer-trimestre-de-2021/

${ }^{42}$ Williams Asha, Martinez Ursula, Guidance Note on Tailoring Adaptive Social Safety Nets to Latin America and the Caribbean; World Bank 2020. 


\section{Bibliography}

Central Bank of the Dominican Republic (2020). Labor Statistics. https://www.bancentral.gov.do/a/d/2541-encuesta-continua-encft

Dirección General de Presupuesto (2020a). Mid-Year Report on the 2020 National Budget). https://www.digepres.gob.do/

(2020b) Reporte Semanal de Ejecución del Gasto al 7 de Diciembre 2020. https://www.digepres.gob.do/

El Día (2020): Ministro de Turismo, David Collado, informó que los hoteles estaban operando a $5 \%$ de su capacidad. August $26^{\text {th }}$, https://eldia.com.do/ocupacion-hotelera-en-el-pais-ronda-el5-informa-david-collado/

Gentilini, U. M. Almenfi, P. Dale, R. Palacios, H. Natarajan, G. Galicia, Y. Okamura, J. Blomquist, M. Abels, G. Demarco and I. Santos (2020). Social Protection and Jobs Responses to COVID-19: A Real-Time Review of Country Measures. "Living paper" version 13 (September 18, 2020), World Bank.

Government of the Dominican Republic (2020). Reports to Bicameral Committee monitoring the Emergency. Consultoría Jurídica del Poder Ejecutivo.

http://www.consultoria.gov.do/News/NewsConsult/8344 Monetaria y Financiera. http://www.consultoria.gov.do/consulta/

Código Tributario de la Republica Dominicana. http://www.consultoria.gov.do/consulta/

Ley 397-19 que crea el Que crea el Instituto Dominicano de Prevención y Protección de Riegos Laborales y modifica Ley 87-01. http://www.consultoria.gov.do/consulta/

Ministry of Economy, Planning and Development (2020). COVID-19 Bajo la Lupa. https://mepyd.gob.do/covid-19-bajo-la-lupa

(2020) Marco Macroeconómico, August 2020 http://mepyd.gob.do/marcomacro.

(2020) SISDOM 2018 and 2019. http://mepyd.gob.do/SISDOM

Ministry of Finance (2020). Forum Section.

https://www.hacienda.gob.do/foro/fase/

https://www.hacienda.gob.do/foro/programa-pa-ti/

Ministry of Finance (2020). Press Section.

https://www.hacienda.gob.do/gobierno-emite-Decree-que-extiende-programas-fase-quedateen-casa-y-pati/

https://www.hacienda.gob.do/ministerio-de-hacienda-garantiza-a-partir-de-hoy-pagos-deprimera-quincena-de-fase/ 
https://www.hacienda.gob.do/foro/main-foro/consulta-programa-pa-ti/paged/10/

National Office of Statistics (2018). Dominican Republic National Multipurpose Household Survey ENHOGAR 2018. Santo Domingo. https://www.one.gob.do/publicaciones

Observatorio del Mercado Laboral Dominicano (2020): Trabajadores suspendidos como impacto del Covid-19 y beneficiarios de los programas Fase 1 y 2: Al 8 de julio 2020. Ministerio de Trabajo.

http://omlad.gob.do/Portals/0/Trabajadores\%20Suspendidos\%20y\%20beneficiario\%20de\%20F ASE\%201\%20Y\%202\%20hasta\%20el\%208\%20julio\%202020.pdf

Progresando Con Solidaridad Program (2020). Monitoring Report I, Stay Home Program, May 2020.

(2020). Monitoring Report II, Stay Home Program, June 2020.

Rodriguez R., Jaime (2020). COVID 19 y suspension de contratos de trabajo en RD. FriedrichEbert-Stiftung (FES). http://library.fes.de/pdf-files/bueros/fescaribe/16183.pdf

Social Policy Coordination Cabinet (2020). Resolution № 001-2020 Institutional Guidelines for Stay Home Program Implementation.

Treasury of Social Security (2020). Statistical Newsletters. https://tss.gob.do/

UNDP (2020a). Impacto Económico y Social del COVID-19 y Opciones de Política en la República $\begin{array}{llllll}\text { Dominicana. } & \text { PNUD } & \text { LAC } & \text { C19 } & \text { PDS } & \text { No. }\end{array}$ https://www.do.undp.org/content/dominican_republic/es/home/library/impacto-economicoy-social-del-coviarad-19-y-opciones-de-politica-e.html

UNDP (2020b). Respuestas para enfrentar la pandemia en América Latina y el Caribe: el uso de programas de transferencias monetarias y de sistemas de información de protección social. $\begin{array}{lllll}\text { PNUD LAC } & \text { C19 } & \text { PDS }\end{array}$ https://www.latinamerica.undp.org/content/rblac/es/home/library/crisis_prevention_and_rec overy/respuestas-para-enfrentar-la-pandemia-en-america-latina-y-el-car.html Vice-Presidency of the Republic (2020). Informe Ejecutivo sobre la Implementación del Programa "Quédate en Casa".

World Bank (2020) Global Findex database. https://globalfindex.worldbank.org/ 


\section{Appendix}

\section{Introduction}

A World Bank review of the building blocks of Social Protection (SP) systems identifies three main dimensions of countries' SP systems.

The first dimension is 'Institutions', including policy setting, legal frameworks, capacity, institutional arrangements, oversight and controls.

A second dimension is 'Delivery', which includes operational processes and functions related to programs and their related delivery systems (including identification, payments and monitoring mechanisms).

Finally, 'Financing' relates to the predictability and sustainability of SP funding.

In the following annexes, this note will analyze the three dimensions of the main social protection programs implemented as a response to the COVID-19 pandemic crisis in the DR: the Stay at Home Program (Quédate en Casa, QEC), the Labor Assistance Fund Program (Fondo de Asistencia Solidaria al Empleado, FASE), and the Self-Employment Assistance Program (Programa de Asistencia al Trabajador Independiente, $\left.\mathrm{PA} \mathrm{A}^{\prime} \mathrm{TI}\right)$.

\section{ANNEX I: Implementing the Stay at Home Program (QEC)}

\section{A. Institutional dimension}

\section{i. Design of the program}

The High-Level Commission for the Prevention and Control of Coronavirus, the Economic Affairs Commission, and the Social Affairs Commission were established by Decree № 132-20 on March 19, 2020, to develop the country's COVID-19 Response Plan and related health, economic, and social policies. These commissions, along with the Vice Presidency and the Ministry of Finance, designed the Stay at Home (Quédate en Casa, QEC) cash-transfer program.

Initially, the Vice Presidency, as Chair of the Social Policy Coordination Cabinet (Gabinete de Coordinación de Políticas Sociales, GCPS) in charge of the non-contributory social protection system in the country, established a working group to elaborate a proposal for presidential revision and approval, with the operational guidelines of the QEC program, in close coordination with the General Directorate of Analysis and Fiscal Policy of the Ministry of Finance. The working group included the Executive Director of the VicePresidency, the Director of the Unified Beneficiary Identification System (Sistema Unico de Beneficiarios, SIUBEN), and the Director of the Administrator of Social Subsidies (Administradora de Subsidios Sociales, ADESS).

The proposal encompassed an analysis of the social and economic effects of the pandemic based on data from SIUBEN and the Progresando con Solidaridad (PROSOLI) program as well as the analytical work on adaptive social protection mechanisms conducted jointly by the GCPS, SIUBEN, and PROSOLI with several international organizations, such as UNDP, WFP, UNICEF, and the World Bank. 
The proposal presented to the president included two possible scenarios with the objective of protecting the income of poor households, informal workers, and the most vulnerable population:

- SCENARIO 1: A temporary monthly cash transfer of RD\$6,067 per household. The amount was based on households' expenses in food and (non-alcoholic) beverage according to the basket of consumer goods for Quintile 1. The duration of the transfer would be 3 months. The target population would be all of households receiving the Comer Es Primero (CEP) program and households identified by SIUBEN as potential beneficiaries of the CEP program.

- SCENARIO 2: A temporary monthly cash transfer of RD\$7,790 per household. The amount was based on households' expenses in food, (non-alcoholic) beverage and medicine according to the basket of consumer goods for Quintile 1 . The duration of the transfer would be 3 months. The target population would be all of households receiving the Comer Es Primero (CEP) program and households identified by SIUBEN as potential beneficiaries of the CEP program.

- COMPLEMENTARY TRANSFER: In both scenarios, a cash transfer of RD\$2,133 was added per household in the case of having a member that is over 60 years and/or with HIV or TB condition.

- COVERAGE: 1,500,000 households, including 452,817 vulnerable households, with 449,730 households with a member that is over 60 years; 2,341 households with people living with HIV/AIDS (PLWHIVs); and 746 households with a member with TB. The share of households to be covered would equal to $46.9 \%$ of all existing households nationwide and $72.5 \%$ of SIUBEN's households.

The president approved the proposal with several modifications and announced it in his Address to the Nation on March 25, 2020, including the following design features:

- Target population: Low-income informal sector workers and families living under vulnerable conditions. Specifically, 811,000 household that received the CEP program. 690,000 additional households categorized as poor or vulnerable by SIUBEN.

- Payment: CEP cardholders (families), who under the regular program receive an average of 1,500 pesos monthly, would receive a two-month increase, for a total cash transfer of 5,000 pesos monthly. Additionally, those households with especially vulnerable members, received an additional 2,000 pesos monthly, totaling 7,000 pesos, for more than 350 thousand households.

- Retail network: The Social Supply Network (Red de Abasto Social, RAS) incorporated 2,000 new retailers to avert any shortage of supplies and effectively respond to the increase in demand.

\section{ii. Legal Framework}

The QEC program's legal framework built on: 1) the country's existing legal, administrative, and operational framework for social protection, especially for the PROSOLI; 2) the state of emergency and administrative acts issued by the president; and 3) Administrative Resolution № 001-2020, issued by the vice president, as Chair of the Social Policy Coordination Cabinet. The administrative resolution retroactively formalized the establishment of the QEC program and set the institutional guidelines for implementation.

The QEC regulatory framework includes:

- Decree № 1082-04, which establishes the Vice-President as the chair of the GCPS to ensure coordination of all plans and programs formulated by participating agencies;

- Decree № 1554-04, which establishes the Social Protection Program to protect the extremely poor and socially vulnerable population from risks; 
- Decree № 1073-04, which establishes SIUBEN as the institution responsible for identifying eligible families for social benefits and subsidies;

- Decree № 1560-04, which establishes ADESS as the unifying social benefit payment body and sets up its institutional and functional links with the GCPS and other government agencies responsible for social subsidies;

- Decree № 536-05, which establishes the Solidaridad program as part of the poverty reduction strategy, including conditional cash transfers to improve the income and human capital of extremely poor families;

- Decree № 426-07, which establishes SIUBEN as an agency under the GCPS, with the responsibility of identifying, characterizing, registering, and prioritizing poor families.

- Decree № 488-12, which establishes PROSOLI, by merging the Progresando and Solidaridad programs, with the objective of enhancing human and social capital as part of the country's overall poverty reduction and human development strategy.

On May 17, 2020, the president, in coordination with the Vice president's office, announced the extension of the QEC program until July. Later, on June 26, 2020, due to the worsening of the pandemic, the president announced that the QEC program, along with other social protection programs would be extended through August $16^{\text {th }}$. This measure was made official with the issuance of Decree № 242-20 on July $8^{\text {th }}$.

When the new administration took office in August 2020, it issued Decree № 358-20, dated August $19^{\text {th }}$, which further extended FASE 1 and 2, the QEC program, and the PA'TI) until December 31, 2020.

Decree № 358-20 established the need to extend social assistance programs until they can be gradually phased out, depending on the economic impact of COVID-19 and instructed the General Budget Office (Dirección General de Presupuesto) to keep separate records of the program expenditures, such that they can later be regularized as part of the national budget.

\section{B. Delivery dimension}

\section{Operational Arrangements}

The QEC program relies on the delivery system and operational guidelines of PROSOLI (CCT), SIUBEN (Identification) and ADESS (Payment) systems.

\section{a. Beneficiary Identification}

- PROSOLI beneficiaries (under CEP and Bonogas Hogar), approximately 811,003 households.

- Households identified by SIUBEN as poor and vulnerable on the most recent survey (2018), but not covered by PROSOLI. A total estimated of 1.5 million households were identified, including an estimated of 66,559 households categorized as Quality of Life Index (QLI) 1 (multidimensional extreme poor), 369,828 households categorized as QLI 2 (multidimensional moderate poor), and the remainder categorized as QLI 3 (multidimensional non-poor and vulnerable).

- QLI 3 households went through additional qualification criteria, as they needed to have: (i) at least one household member over 60 years old; (ii) at least one small child or infant; (iii) at least one schoolaged child; (iv) members with pre-existing health conditions; (v) members with HIV and/or TB and/or cancer; (vi) members with a disability; and (vii) members working in the informal labor market. The 
informal labor market status of QLI 3 households was determined by cross-checking the SIUBEN database with the Treasury of Social Security (TSS) database.

- In April 2020, the vice president announced that 70,000 new households would be incorporated into the QEC program to include informal-sector workers, including beauty parlor workers; motorcyclists; cab drivers; odd-jobbers (chiriperos); people working for civil society organizations helping PLWHAs; artisans; and street vendors. This new group of beneficiaries was selected from nearly one million applications received and filtered by cross-checking the SIUBEN, TSS, FASE, and QEC databases.

\section{b. Communication Strategy}

- A committee was established to implement the communication mechanisms, that included the Division of Communications of the Vice Presidency, the Administrative Ministry of the Presidency, the Ministry of Finance, and the Division of Communications of the Presidency.

- Communication mechanisms consisted of digital, print, and social media, radio, and television to inform the population about the program, including:

- Presidential and vice-presidential addresses (e.g., the Vice President Address to the Nation was used from time to time to inform the public about the program);

- Interviews with the vice president and directors of institutions responsible for executing the program;

- Press releases published from the vice president, ADESS, PROSOLI, SIUBEN, and the GCPS in national newspapers and on institutional web portals and social networks;

- With INDOTEL's support, ADESS identified effective ways of contacting new beneficiary households by telephone to inform them of their inclusion in the program and corroborate data for processing cash transfers.

- Text messaging or SMS to beneficiaries with important information, including payment dates, retailer information, etc.

- Instructional, informational, and promotional material published in different digital media (and some cases in printed format), such as RAS retail leaflets, kits, and guides for retailers with instructions on how to manage customers, prevent store crowding, and facilitate transaction processes, etc.;

- Punto Solidario discussion forums (http://vicepresidencia.puntosolidario.gob.do/forum/);

- Web query portal (https://www.quedateencasa.gob.do/Default.aspx) to verify QEC beneficiaries' affiliation status;

- Telephone query lines (809-920-2081, 1-809-200-0063, and 1-809-200-0064) to strengthen the capacity of the ADESS' call center and accurately support beneficiaries; and

- Communication strategies to counteract inaccurate information and prevent fraud.

\section{c. Payment Mechanisms}

O In coordination with commercial banks and merchant processing service providers (i.e., VISANET and CARDNET), ADESS identified a new payment mechanism using the national identification document (ID). ADESS adjusted its operational guidelines to the new payment mechanism.

- ADESS already had a contractual relation with the banks and VISANET and CARDNET, but terms of reference were flexible enough to allow for adaptations required for the development of the new payment method.

- CARDNET and VISANET implemented technological solutions to ensure retailer stores were able to accept the beneficiary heads' of household IDs as a means of transaction. 
- ADESS facilitated a database of beneficiaries' ID numbers to the Reserve Bank. The Reserve Bank opened virtual accounts for beneficiaries with ID cards. Accounts were then linked to beneficiaries with an associated validation code, which functions as an e-wallet. The e-wallet is credited twice a month, and the beneficiary may visit any RAS-affiliated retailer to purchase food and non-alcoholic beverages and other authorized basic goods. This dramatically reduced the card issuance time while simplifying RAS payment procedures and prevented unnecessary personal contact during card distribution and other processes.

- To activate IDs as a means of payment, beneficiaries had to validate their data through the QEC portal (www.quedateencasa.gob.do) or receive a verification call from ADESS.

O The QEC's payroll process was integrated into the recurrent operations of PROSOLI and ADESS, supported by the existing and successful payment platform created in 2005.

- QEC cash transfers are deposited directly to beneficiaries' cards or virtual accounts to purchase eligible basic food and products in local retailers (colmados), supermarkets, and other authorized stores, in line with their membership with the RAS. Beneficiaries spending translates into sales revenue for these stores, creating a ripple effect in the economy and fostering local production, which benefits micro and small and enterprises, farmers, transportation firms, and small local suppliers.

- Beneficiary families receive a semi-monthly payment of $\operatorname{RD} \$ 2,500$ on four different payment dates: two times per month for permanent PROSOLI beneficiaries and two different times per month for temporary beneficiaries. The reason for this is to avoid overcrowding at stores and pent up demand. New cardless beneficiaries will receive their subsidy payments on the $7^{\text {th }}$ and $20^{\text {th }}$ of the month, while cardholders will receive them on the $3^{\text {rd }}$ and $17^{\text {th }}$ of the month.

\section{d. Store Support Services under the Social Supply Network (RAS)}

0 As PROSOLI beneficiaries increased by 80 percent and the number of payment transactions increased by 600 percent, ADESS expanded the RAS network, incorporating up to 2,000 new retailers (including supermarkets), with pending membership approvals, totaling 5,500 points of sale.

- RAS retailers are receiving support from ADESS to ensure effective transactions for beneficiaries. ADESS provided kits and retailer guidelines on how to manage customers, prevent store crowding, and facilitate transaction processes. Social media has been used to provide retailers with important information.

- ADESS implemented a strategy to exclude non-compliant retailers and prosecuting fraud and scams to protect the integrity of the benefit payment system. Some opportunities for improving fraud prevention have been identified, including the need to ensure vouchers or receipts detailing transactions and purchased items are provided to beneficiaries, as well as ensuring that beneficiaries' ID information is handled securely by store personnel.

- ADESS coordinated with PROCONSUMIDOR measures to monitor prices and sales conditions at RAS retailers.

- ADESS expanded the basic package of essential products to include feminine hygiene products as QEC benefits.

\section{e. Monitoring \& Evaluation}

ADESS, PROSOLI, and the GCPS Technical Directorate use different mechanisms to monitor and follow up the implementation of the QEC program, including:

- ADESS monitors the payment system by reviewing indicators such as transaction volume, average transaction amount, and use of funds (within the month of the original transfer); 
- PROSOLI conducted two telephone monitoring surveys, sampling 3,231 beneficiary households;

- Participatory monitoring using the Community Reports (CR) mechanism, which involves more than forty-two PROSOLI beneficiary family groups (Nucleos de Familias Solidarias) from the top ten provinces with the highest concentration of extremely poor households;

- ADESS-led telephone-based grievance redress monitoring mechanism and the one-stop customer service window to provide support to beneficiaries, including the most vulnerable households (Punto Solidario);

- Regular reports sent to the president for subsequent submission to the National Congress; and

- Participation in weekly follow-up meetings held in the context of the Group for Adaptative Social Protection, a coordination platform between social protection government institutions, United Nations agencies, including WFP, UNDP, UNICEF, UNFPA, IOM, UNHCR and FAO, and the World Bank. Coordination activities are based on the Adaptive Social Protection approach, where feedback, guidance, technical assistance, and additional resources are provided to inform the design and implementation of the QEC program.

\section{Financing dimension}

\section{Financing Mechanism}

- The Ministry of Finance provided the necessary financial resources and administrative mechanisms, based on the current legal framework (i.e., National Budget Law and the state of emergency), to finance the QEC program.

- An initial RD\$16-billion financing requirement was established to implement the QEC program in April and May. Upon completion of this period, the GCPS' Administrative and Financial Office submitted a request for additional funds to the General Budget Office, following appropriate budget regulations and procedures.

\section{Coordination Arrangements}

The Social Affairs Commission, responsible for distributing raw food rations, coordinated with the GCPS to use the QEC distribution map, to prioritize the delivery of rations to areas with the lowest QEC program coverage. Institutions responsible for food distribution have a nationwide scope and include Comedores Económicos, the Social Assistance Plan of the Presidency (PASP), the National Institute of Student Welfare (INABIE), and the National Institute for Comprehensive Early Childhood Care (INAIPI). 


\section{ANNEX II: Implementing the Labor Assistance Fund Program (FASE)}

\section{A. Institutional dimension}

\section{Design of the program}

The Labor Assistance Fund Program (Fondo de Asistencia Solidaria del Empleado, FASE) was created in the context of the same High-Level Commissions that created the QEC program. In particular, the Economic Affairs Commission facilitated the inter-sectoral coordination between the Ministry of Finance, which presides this Commission, and the Ministry of Labor for the design and monitoring of the FASE.

In his Address to the Nation on March 25, 2020, the president announced the FASE, a program intended to provide protection to formal workers, as part of the key set of economic measures adopted by the government to mitigate the effects of the pandemic crisis.

On March $26^{\text {th }}$, the Minister of Finance made statements to further elaborate on the FASE, pointing out that it targeted workers whose companies contribute to the Treasury of Social Security (TSS) and have been forced to suspend operations due to the COVID-19 social distancing measures. FASE's objective is to prevent job loss and allow workers to preserve part of their income.

FASE includes two kinds of support: one for workers with suspended employment contracts (FASE 1) and another for workers with active employment contracts (FASE 2).

FASE 1 provides a monthly cash transfer, ranging from $\operatorname{RD} \$ 5,000$ to $\operatorname{RD} \$ 8,500$. The employer needs to notify the furlough to the Ministry of Labor. Then the government pays a subsidy of up to 70 percent of the employee's salary (according to the last salary reported to the TSS as of February 2020, payable on a semi-monthly basis. In cases where the subsidy does not cover the full amount of the employee's salary, Decree № 143-20 urges employers to pay the remaining amount, but it is not mandatory.

FASE 2 covers employees whose companies are still operating and are micro, small and medium-sized enterprises (MSME), or belong to the manufacturing sector, or are an eligible large enterprise, according to the established criteria under Decree 184-20. FASE 2 can also support employees of companies that have ceased operations but kept all their workforce on payroll and kept contributing to the TSS.

FASE 2 grants a monthly subsidy of RD\$5,000 to the employee as salary advance. However, the employer is still liable for covering the worker's remaining compensation and any other labor costs, including social security contributions and labor benefits. FASE benefits are neither subject to tax with holding obligations nor considered when computing the annual Christmas bonus $\left(13^{\text {th }}\right.$ salary) or social security contributions.

If an employee has been laid off from two or more formal jobs, the employee is entitled to the transfer benefit for the highest-paying job. The criteria for defining FASE eligibility restrictions and benefits under the FASE program are not publicly available. 


\section{Legal Framework}

On April 2, 2020, Decree № 143-20, established the FASE program. Decree № 143-20 excluded from FASE employees of certain essential industries such as health businesses, media businesses, restaurants, ice cream parlors, private security firms, universities, and government-sponsored non-governmental organizations,

Some legal adjustments to the program were introduced to broaden its scope. Decree № 184-20, dated May 29 ${ }^{\text {th }}$, amended Articles № 5, 6, 7, 8, and 9 of Decree № 143-20 to cover more employees of sectors previously excluded. It also made employers with both furloughed and active employees eligible to access the program. The government did the expansion in response to worsened economic conditions and to the requests of business associations. Decree № 184-20 also extended the duration of the program for an additional thirty days to June $1^{\text {st }}$.

Decree № 242-20, dated July $8^{\text {th }}, 2020$, extended the duration of the FASE program, along with other social programs implemented to respond to the COVID-19 crisis, to August $16^{\text {th }}$.

Employees of large essential businesses (other than MSMEs) remained excluded from FASE, including:

- Supermarkets, grocery stores, pharmacies, and any commercial establishments selling raw food, medicines, and hygiene products;

- Logistics, distribution, and transportation companies shipping unprocessed materials and finished products for industry, agro-industry, and food industry;

- Agriculture, livestock, and fisheries;

- Food industries;

- Mining and quarrying;

- Food, pharmaceutical, and agro-industrial distribution warehouses;

- The financial sector, pension fund administrators, occupational risk administrators, and insurance providers;

- Energy generation plants;

- Businesses in the health sector, except for dentists, skincare centers, psychological therapy centers, plastic surgery facilities, beauty salons, hair transplant centers, private clinic labs, and animal hospitals; and

- Telecommunications businesses.

When the new administration took office in August 2020, it issued Decree № 358-20, dated August $19^{\text {th }}$, which further extended FASE 1 and 2, the QEC program, and the PA'TI until December 31, 2020. Decree № 358-20 established the need to extend social assistance programs until they can be gradually phased out, depending on the economic impact of COVID-19 and instructed the General Budget Office (Dirección General de Presupuesto) to keep separate records of the program expenditures, such that they can later be regularized as part of the national budget.

\section{B. Delivery dimension}

\section{Operational Arrangements}


Article 8 of Decree № 143-20, later amended by Decree № 184-20, tasked the Ministry of Finance and the Ministry of Labor, in coordination with the Dominican Institute for the Prevention and Protection of Occupational Risks (IDOPPRIL), to implement and manage the FASE program. The implementation of the program relied on the close coordination between the Ministry of Finance and the Ministry of Labor.

\section{a. Beneficiary Identification}

- In early April 2020, the Ministry of Labor created a user-friendly online application tool for the FASE program (http://fase.mt.gob.do/web/), where employers submitted applications on behalf of their employees. For FASE 1, registered employers signed in and applied for the suspension of employment contracts by filling in the corresponding digital forms, which were recorded by the Ministry of Labor's Integrated Labor Registration System (SIRLA). A similar procedure was followed for FASE 2, except that there was no need to apply for a work contract suspension.

- On the Ministry of Labor's FASE portal, employers accessed the FASE form and provided information on the employees joining program, including the employees' bank account numbers where they wish to have the benefits deposited.

0 Both the Ministry of Finance and the Ministry of Labor have published step-by-step instructions to guide applicants:

- $\quad$ https://transparencia.hacienda.gob.do/documents/20127/319327/INSTRUCTIVO+FASE.pdf/Oa5 371c7-43fb-04fd-4c76-736d68a33a4d; and

- https://www.mt.gob.do/fase/wp-content/uploads/2020/04/FASE Instructivo-COMP.pdf.

- The Ministry of Labor created a database with employers' applications to FASE 1 and 2, as applications were received. This ministry cross-checked information with the TSS to validate contributions and eligibility criteria. Also, the ministry verified that applicants were not receiving benefits under the QEC or PA'TI programs. A final database was created with the eligible workers' banking information, including the name of the financial institution and account type and number, which was submitted to the Ministry of Finance for completing the payment process.

\section{b. Communication Strategy}

- The government deployed different communication strategies for the FASE program. First, the president announced the program during his Address to the Nation on March $25^{\text {th }}$, and the Ministry of Finance held a virtual press conference on March $26^{\text {th }}$. This was followed by detailed information on the program, instructions for potential beneficiaries, and program progress posted on the social media accounts of the Ministry of Labor and Ministry of Finance, including Twitter (@MTrabajoRD and @MinHaciendard) and Facebook (@MTrabajoRD and @MinHaciendaRD).

- In early April, the Ministry of Labor created an online web portal (http://fase.mt.gob.do/web/) to process FASE applications and make it possible for the public to access instructions, make queries, and obtain key information about the program.

- Two websites were also created (in coordination with the QEC program) where FASE membership can be verified: https://www.hacienda.gob.do/consulta-afiliacion-fase/ and https://www.quedateencasa.gob.do/Default.aspx.

- The Ministry of Finance also created FAQ forums regarding the FASE program on its web portal: https://www.hacienda.gob.do/foro/fase/.

- Different press releases on program implementation have been published in key national newspapers and the institutional web portals of the Ministry of Finance and the Ministry of Labor. 
- Responding to growing demand for information, two telephone lines were set up jointly with PA' TI program to address concerns, complaints, and claims: 809-688-8838 and 809-686-0092. Information was also distributed via interviews, virtual conferences, and presidential and ministerial addresses

- Employers and employees are encouraged to play a proactive role in contacting the Ministry of Labor and/or the Ministry of Finance to confirm if they have actually received the benefits.

\section{c. Payment Mechanism}

O Once the eligible employees' information has been validated, the Ministry of Labor prepares and sends the payroll and payment instructions to the Ministry of Finance.

- Upon receiving this information from the Ministry of Labor, the Ministry of Finance processes the payments and emails a notice to both the employer and employee, when possible.

- Government contributions are deposited directly into the employees' payroll accounts reported by their employers. In cases when the employee had no formal financial account, a payroll account was opened in his or her name at the Reserve Bank. No retroactive payments are made.

$O$ Both the Ministry of Finance and the Ministry of Labor have websites where workers can check if their employer has registered them as FASE beneficiaries:

- https://www.hacienda.gob.do/consulta-afiliacion-fase/;

- https://www.quedateencasa.gob.do/Default.aspx.

- It is not known if the banking institutions that receive the beneficiaries' cash transfers have introduced additional security and anti-fraud measures.

- In July 2020, the Ministry of Finance reported delays in the disbursement of funds due to adjustments made to the internal payment processing system when the program was extended.

\section{d. Monitoring \& Evaluation}

- The information available on monitoring and evaluation strategies for the FASE program is limited. Information on program progress and accountability reports on the number of beneficiaries, amounts invested, and characteristics of the target population are also limited.

- While a follow-up mechanism for the program had been contemplated through the Economic Affairs Commission, which includes the Ministry of Finance and the Ministry of Labor, detailed information publicly available is scarce. Progress reports are regularly submitted to the president, which are then forwarded to the National Congress.

- No information has been made public related to what other indicators (process, effectiveness, and results) and targets are used to monitor and evaluate program activities and how they are measured. Moreover, it is unclear if the authorities have used data collected to improve the program, and if so, what indicators have been the most relevant, and what has been the result of targeted measures in terms of program objectives and targets. Finally, it is unclear if the Ministry of Labor and/or the Ministry of Finance plan to conduct an impact evaluation or any other specialized type of assessment for the FASE.

\section{Financing dimension}

\section{Financing Mechanism}

- The FASE program's financing sources include the Dominican Institute for the Prevention and Protection of Occupational Risks (IDOPPRIL). IDOPPRIL was established by Law $\mathrm{N}^{\circ}$ 397-19, whose Article $\mathrm{N}^{\circ} 21$ states that funds from past contributions, profits, or benefits accumulated in managing 
the Labor Risk Insurance scheme can be used for projects and programs aimed at the economic, social, occupational, or health protection of workers. However, the procedures implemented by the government to access these resources for subsequent transfer to the beneficiaries are not known.

- An initial RD\$17 billion financing requirement was established to implement the FASE program in April and May. 


\section{ANNEX III: Implementing the Self-Employment Assistance Program (PA'TI)}

\section{A. Institutional dimension}

\section{Design of the program}

The same High-Level Commission that created the FASE program (Economic Affairs Commission), created the Self-Employment Assistance Program (Programa de Asistencia al Trabajador Independiente, PA'TI).

The PA'TI program was announced by the president in his Address to the Nation on May 17, 2020, and he stated that it would target informal self-employed workers not currently supported by the FASE or QEC programs. The PA'TI program would support eligible self-employed workers through a temporary unconditional cash transfer to counteract the negative economic effects of lockdown measures implemented to slow the spread of COVID-19.

\section{Legal Framework}

The PA'TI program was officially established by Decree № 185-20 on May 29, 2020. According to Article 3 , beneficiaries would receive $\operatorname{RD} \$ 5,000$ each month, which is not subject to any tax withholding obligation. This amount is equivalent to the base amount received by QEC and FASE beneficiaries.

The initial duration of the PA' TI was thirty days, starting on June $1^{\text {st }}$. On June 26,2020 , the president announced that the PA'TI, along with other social programs implemented during the crisis, would be extended until August $16^{\text {th }}$ due to the worsening of the pandemic. This measure was formalized by Decree № 242-20, dated July $8^{\text {th }}, 2020$.

When the new administration took office in August 2020, it issued Decree № 358-20, dated August $19^{\text {th }}$, which further extended FASE 1 and 2, the QEC, and the PA'TI until December 31, 2020. Decree № 358-20 established the need to extend social assistance programs until they can be gradually phased out, depending on the economic impact of COVID-19 and instructed the General Budget Office (Dirección General de Presupuesto) to keep separate records of the program expenditures, such that they can later be regularized as part of the national budget.

\section{B. Delivery dimension}

\section{Operational Arrangements}

Article 5 of Decree № 185-20 tasked the Ministry of Finance to implement and manage the PA'TI program. For this purpose, this ministry set up a new cash transfer management platform to deliver benefits to its target population and linked it to the banking system.

The implementation of the PA'TI program also required the Ministry of Finance to develop a series of key partnerships, especially to identify eligible beneficiaries and deliver payments. For example, to determine the total population of eligible self-employed workers and select beneficiaries, an unprecedented exchange of information was required between different agencies, including the Superintendency of Banks; Banca Solidaria (through the National Council for the Promotion and support of the Micro, Small and Medium-sized Enterprise, PROMIPYME); the Vice-Ministry for MSME Development under the 
Ministry of Industry and Trade (MICM); the Treasury of Social Security (TSS); the Dominican Internal Revenue Service (Dirección General de Impuestos Internos, DGII); the Ministry of Labor; ADESS; and the Reserve Bank.

To implement the PA'TI program, the Ministry of Finance appointed a technical team that included a developer, a business area manager, and a development area manager.

\section{Beneficiary Identification}

- In conformity with Article 3 of Decree № 185-20, eligible self-employed workers under the PA'TI program must have a valid ID document and demonstrate that on or after February 29, 2020, they had taken out a loan with a financial institution governed by the Superintendency of Banks or with a central government-administered financing program.

- Self-employed workers must meet the following eligibility requirements:

1. They are not contributing to social security as of February 29, 2020;

2. They are not beneficiaries of QEC or FASE;

3. They are not classified as a local or national large enterprise if they file taxes with the DGII; and

4. Their tax return payments do not exceed RD\$150,000.00 in one fiscal year if they file taxes with the DGII.

- Based on the eligibility requirements, the Ministry of Finance identified eligible beneficiaries by crosschecking data managed by the following organizations:

- The Superintendency of Banks and Banca Solidaria of PROMIPYME provided a list of people registered as self-employed workers with loans in the formal financial system, including their identity cards and bank account numbers;

- The Vice-Ministry for MSME Development under the MICM provided access to its microenterprise database;

- The Treasury of Social Security (TSS) provided access to its database to verify that applicants were not contributing to social security by February $29^{\text {th }} 2020$;

- The DGII verified that the applicant had not: (i) filed tax returns with cumulative tax payments exceeding $\mathrm{RD} \$ 150,000.00$ in one fiscal year; and (ii) registered a large enterprise; and

- The Ministry of Labor and ADESS provided access to the beneficiary databases of FASE and QEC, respectively, to verify that the applicant had not received social assistance from these programs.

- Based on the cross-checking exercise, the Ministry of Finance announced on May 19, 2020, that it had identified $202,405^{43}$ self-employed workers as PA'TI beneficiaries. ${ }^{44}$

- As of June 3,2020, upon defining the target population, the Ministry of Finance created a web portal (https://pati.hacienda.gob.do/buscar) on June 3, 2020, where people could check whether they were eligible or not. Beneficiaries could also use the web portal to edit their information in case of errors or

${ }^{43}$ Data available in the Executive Branch's Report to Congress, dated July 10, 2020, estimated that PA'TI had benefited 189,767 people. Data presented by the Ministry of Finance's technical team representing the PA'TI program in a virtual meeting held with UN agencies and stakeholders of the country's social protection system on July 15 indicated that PA'TI had a total of 189,864 beneficiaries. The discrepancy between the original and actual number of beneficiaries (about 12,541 less) is not well understood. While there have been some issues with beneficiary account data, the number of people affected is unclear. Thec questions should be raised with the Ministry of Finance's technical team.

${ }^{44}$ In addition to the aforementioned PA' TI eligibility criteria, further details on the program beneficiary's socioeconomic characteristics are unknown, and the PA'TI team at the Ministry of Finance has indicated that it has no access to further information. 
inconsistencies. ${ }^{45}$ Moreover, the web portal featured an on-demand application form for the PA'TI program that workers could use to apply to the program. These applications also went through the Ministry of Finance's data purging and validation process. By July 15, 2020, the web portal had received $3,560,797$ queries and 65,809 on-demand self-inclusion applications, of which only 3,069 were approved.

\section{Communications Strategy}

- The government deployed different communication strategies for the PA' TI program, starting with the president's Address to the Nation on May $17^{\text {th }}$ and a virtual press conference held by the Ministry of Finance on May $19^{\text {th }}$. The authorities used the social media accounts of the Ministry of Labor and Ministry of Finance, especially Twitter (@MTrabajoRD and @MinHaciendard) and Facebook (@MTrabajoRD and @MinHaciendaRD), to provide detailed information about the program, instructions for potential beneficiaries, and progress updates. In turn, the MIC reposted this information on its social media accounts.

- In early June, the Ministry of Finance made it possible for beneficiaries to use its web portal (https://pati.hacienda.gob.do/) to check their application status, edit/confirm their bank account information, and submit on-demand applications. This web portal has been created in addition to the previous web portals for the QEC and FASE. Moreover, the Ministry of Finance created different FAQ forums on its web portal for citizens and beneficiaries to access information on the PA' TI program (https://www.hacienda.gob.do/foro/programa-pa-ti/). It also published press releases related to the PA' TI program in key national newspapers to brief the public on the implementation of the program.

- In response to growing demand for information from the public on social media platforms and forums, the Ministry of Finance made it possible for beneficiaries to contact the program to voice concerns, complains, or claims they may have. The ministry provided an email address (pati@hacienda.gov.do) that the public could use, and a telephone support line (809-688-8838, 809-686-0092) was set up jointly with the FASE program.

- The authorities also made sure to continuously broadcast information via interviews, virtual conferences, and speeches given by the president, vice president, and other high-level officials.

- Despite the government's information campaigns, information on program progress and accountability reports on the number of beneficiaries, amounts disbursed, and characteristics are very limited.

- In a virtual meeting held with United Nations agencies and stakeholders of the country's social protection system, the Ministry of Finance's technical team representing the PA' TI program stated that they lacked contact information for beneficiaries, which is a serious challenge. They also stated that the dataset containing information on a worker's identification card, bank account numbers, and loans they receive from the Superintendence of Banks does not include contact information such as phone numbers or e-mails.

- Beneficiaries are encouraged to play a proactive role in contacting the Ministry of Finance to confirm if they have received benefits. Communication options have, however, been primarily restricted to websites and telephone support. While the Ministry of Finance is not required to reach out the beneficiaries and provide all relevant information, Decree № 185-20 instructs the ministry to notify the beneficiary about assistance payments.

\section{Payment Mechanism}

\footnotetext{
${ }^{45}$ Details on the on-demand application purging process are not available. Also, the reason why these applicants were not selected for the original purged list is not known.
} 
- Once the target population had been identified, in conformity with Article 5 of Decree № 185-20, the Ministry of Finance prepared and issued the payments, notifying the financial intermediary institutions of payments processed.

- The payment, which is not subject to any tax withholdings, is made every month via a cash transfer to the bank account associated with the eligible worker, according to the records received by the Superintendency of Banks and Banca Solidaria.

- According to the PA'TI program's technical team, some of the complaints the Ministry of Finance has received via its web portal regarding issues beneficiaries have had with the cash transfers were due to inactive or canceled bank accounts.

- The Ministry of Finance allowed beneficiaries to access their accounts on the web portal (https://pati.hacienda.gob.do/inicio) to ensure their information was correct and up-to-date, in effect, making beneficiaries responsible for their information so they can receive benefits.

- As indicated by the Ministry of Finance's technical team representing the PA' TI program in a virtual meeting held with United Nations agencies and stakeholders of the country's social protection system on July 15, 2020, approximately 15 percent of the target population had no traditional bank accounts. Instead, they had an account or loan with a cooperative. In such cases, beneficiaries were required to open an account with Banreservas and update their data to receive the cash transfer, an issue that has caused payment delays.

- It is not known if the banking institutions receiving the beneficiary cash transfers have introduced additional security and anti-fraud mechanisms to protect beneficiaries.

\section{Monitoring \& Evaluation}

- The information available on monitoring and evaluation strategies for the PA' TI program is limited. In the virtual meeting held with program stakeholders, the Ministry of Finance's technical team showcased an internal dashboard with applications and payments used to monitor the implementation of the program. They presented some screenshots of the dashboard showing statistics on PA'TI web portal queries, applications received, approved, and rejected, the number of beneficiaries, and monthly payments. However, this information is not available to the public on the website of the Ministry of Finance.

- No information has been made public related to what other indicators (process, effectiveness, and results) and targets are used to monitor and evaluate program activities and how they are measured. Moreover, it is unclear if the authorities have used data collected to improve the program, and if so, what indicators have been the most relevant, and what has been the result of targeted measures in terms of program objectives and targets. Finally, it is unclear if the Ministry of Finance plans to conduct an impact evaluation or any other specialized type of assessment for the PA'TI program.

- While a follow-up mechanism had been contemplated for the PA'TI program in the context of the Economic Affairs Commission, detailed publicly available information is very scarce.

- Program progress reports are submitted regularly to the president, which are eventually forwarded to the National Congress. 


\section{Financing dimension}

\section{Financing Requirements}

- The PA' TI program's financial arrangements fall under the responsibility of the institutions led by the Ministry of Finance, which provide the necessary legal mechanisms based on the current legal framework (i.e., the National Budget Law and the state of emergency).

- Based on the initial identification of 202,405 self-employed workers, the authorities estimated that $\mathrm{RD} \$ 2,024$ billion was required to implement the PA'TI program in May and June. 